Canadian

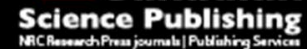

Canadian Journal of Chemistry Revue canadienne de chimie

\title{
n-Extended Fluoranthene Imide Derivatives: Synthesis, Structures, and Electronic and Optical Properties
}

\begin{tabular}{|r|l|}
\hline Journal: & Canadian Journal of Chemistry \\
\hline Manuscript ID & cjc-2016-0488.R1 \\
\hline Danuscript Type: & Tribute \\
\hline Complete List of Authors: & $\begin{array}{l}\text { Kawajiri, Ikumi; University of Hyogo, Graduate School of Applied Chemistry } \\
\text { Nagahara, Masaya; University of Hyogo, Graduate School of Applied } \\
\text { Chemistry } \\
\text { Ishikawa, Hiroyuki; University of Hyogo, Graduate School of Applied } \\
\text { Chemistry } \\
\text { Yamamoto, Yuma; University of Hyogo, Graduate School of Applied } \\
\text { Chemistry } \\
\text { Nishida, Jun-ichi; University of Hyogo, Graduate School of Applied } \\
\text { Chemistry } \\
\text { Kitamura, Chitoshi; The University of Shiga Prefecture, School of } \\
\text { Engineering } \\
\text { Kawase, Takeshi; University of Hyogo, Graduate School of Applied } \\
\text { Chemistry }\end{array}$ \\
\hline Keyword: & $\begin{array}{l}\text { imides, n-extended fluoranthene, fluorophore, self-aggregation, } \\
\text { solvatochromism }\end{array}$ \\
\hline
\end{tabular}


$\pi$-Extended Fluoranthene Imide Derivatives: Synthesis, Structures, and

\section{Electronic and Optical Properties}

Ikumi Kawajiri, ${ }^{1}$ Masaya Nagahara, ${ }^{1}$ Hiroyuki Ishikawa, ${ }^{1}$ Yuma Yamamoto, ${ }^{1}$ Jun-ichi Nishida, ${ }^{1}$

Chitoshi Kitamura, ${ }^{2}$ and Takeshi Kawase ${ }^{1}$

${ }^{1}$ Graduate School of Engineering, University of Hyogo, 2167 Shosha, Himeji, Hyogo 671-2280, Japan

${ }^{2}$ School of Engineering, The University of Shiga Prefecture, 2500, Hassaka-cho, Hikone, Shiga 522-8533, Japan

Corresponding author email: kawase@eng.u-hyogo.ac. jp tel. +81-79-267-4889, fax +81-79-267-4889 


\section{Abstract}

Diels-Alder reactions of acenaphthylene-5,6-dicarboximide (AI) derivatives with the corresponding dienes

afforded some derivatives of $\pi$-extended fluoranthene imide, namely $N$-(2-ethylhexyl)-7,10-diphenylfluoranthene

imide (DPFI) and $N$-(2-ethylhexyl)-7,8,9,10-tetraphenylfluoranthene imide (TPFI),

$N$-(n-octyl)-benzo[ $k]$ fluoranthene imide (BFI), and $N$-(n-octyl)-naphtho $[k]$ fluoranthene imide (NFI). Molecular

structures of TPFI and BFI reveal that the core $\pi$-skeletons have a highly planar structure, and the molecules form

a dimeric structure in the crystals. The absorption spectra exhibit bathochromic shift with $\pi$-extension of the core

$\pi$-skeletons. On the other hand, DPFI and TPFI show the long-wavelength emission related to BFI, probably due to $\pi$-extension toward the phenyl substituents in the excited states. BFI and NFI exhibited an interesting

concentration-dependent ${ }^{1} \mathrm{H}-\mathrm{NMR}$ behavior in $\mathrm{CDCl}_{3}$, suggesting self-aggregation formation. Moreover, $\mathbf{B F I}$ and NFI show moderate and remarkable solvatofluorochromism in solutions $\left(\mathbf{B F I}\right.$ for $\Delta \lambda_{\mathrm{EM}}=67 \mathrm{~nm}, \mathbf{N F I}$ for $\Delta \lambda_{\mathrm{EM}}=$ $116 \mathrm{~nm}$ ), respectively, while DPFI and TPFI show weak solvatofluorochromism. The density functional theory calculations demonstrate that the considerable spatial separation between the HOMO and LUMO coefficients in the NFI molecule. The result indicates that the ground-to-excited state transition of NFI should have intramolecular charge transfer (ICT) character.

Key words: imides, $\pi$-extended fluoranthene, fluorophore, self-aggregation, solvatochromism, crystal structure

\section{Introduction}

Fluorophores have received considerable attention as sensors owing in part to their extreme sensitivity to subtle

environmental changes that are signaled by changes in either their fluorescence intensities or wavelengths. ${ }^{[1]}$ One 
sub-class of sensors called solvatochromic fluorophores usually possesses "push-pull" structures bearing opposed electron-donating and -withdrawing groups. ${ }^{[2]}$ In general, theoretical calculations of these fluorophores indicate the existence of excited state intramolecular charge transfer (ICT) between the electron-donating and -withdrawing groups. ${ }^{[3]}$ Polycyclic aromatic hydrocarbon (PAH) possessing an imide group would be promising model compounds having a "push-pull" structure, ${ }^{[1 \mathrm{~d}, 4]}$ because the imide group can be act as an electron-withdrawing group and the PAH moiety with high HOMO energy level should act as an electron-donating group. Imide derivatives involving a fluoranthene moiety, namely fluoranthene imides (FI), have recently emerged as an important class of compounds exhibiting intense fluorescence and n-type of semiconducting properties. ${ }^{[5]}$ However, to the best of our knowledge, no FI derivatives have been known to exhibit a solvatofluorochromic property. Acenaphthene-5,6-dicarboximides (AI) 1 would be a versatile synthon for construction of the FI derivatives, because the AI possesses a highly reactive $\mathrm{C}-\mathrm{C}$ double bond ascribed to the ring strain of the fused cyclopentene ring. Thus, the Diels-Alder reactions of $\mathbf{1}$ with appropriate dienes should produce the variety of the FI derivatives. However, only a few studies have been performed to date ${ }^{[6]}$ To elucidate the insight into the relationship between the structural and optical properties, we synthesized $\pi$-extended FI derivatives, namely $N$-(2-ethylhexyl)-7,10-diphenylfluoranthene 3,4-dicarboximide (DPFI: 2a) and $N$-(2-ethylhexyl)-7,8,9,10-tetraphenylfluoranthene3,4-dicarboximide (TPFI: 3a), and $N$-(n-octyl)-benzo[k]fluoranthene 3,4-dicarboximide (BFI: 4b) and $N$-(n-octyl)-naphtho[k]fluoranthene 3,4-dicarboximide (NFI: 5b), from the corresponding AI derivatives (1a and $\mathbf{1 b}$ ) (Scheme 1), respectively. We found that $\mathbf{4 b}$ and $\mathbf{5 b}$ exhibit moderate and large solvatofluorochromism in organic solvents and formed self-aggregates in $\mathrm{CDCl}_{3}$. It has been known that diimide derivatives bearing a PAH moiety construct various 
supramolecular architectures by self-aggregation in solution. ${ }^{[7]}$ On the other hand, few monoimide derivatives bearing a simple $N$-alkyl group cause self-aggregation in organic solvents. We recently reported as a rare example that $N$-(n-octyl)acenaphtho[1,2-j]fluoranthene imide (6b) exhibits self-aggregation behavior in $\mathrm{CDCl}_{3} \cdot{ }^{\left[{ }^{8]}\right.} \mathrm{We}$ here describes the structural, electronic, optical and supramolecular properties of the $\pi$-extended FI derivatives together with density functional theory (DFT) calculations ${ }^{[9]}$ as helpful information.

$<$ Scheme 1 $>$

\section{Results and Discussion}

Synthesis of $\pi$-extended fluoranthene imides

The acenaphthene imides $\mathbf{1 a}$ and $\mathbf{1 b}$ were prepared from acenaphthene-5,6-dicarboxylic anhydride (7) via the corresponding acenaphthene imides $\mathbf{8 a}$ and $\mathbf{8 b}$ (Scheme 2). ${ }^{[10]}$ The Diels-Alder reactions of $\mathbf{1 a}$ with

2,5-diphenylthiophene 1,1-dioxide (9) ${ }^{[11]}$ and tetracyclone $\mathbf{1 0}$ were examined; the reaction mixtures of $\mathbf{1 a}$ and the dienes in $o$-xylene were heated at reflux for $24 \mathrm{~h}$. Under the reaction conditions, subsequent aromatization occurred to form 2a and $\mathbf{3 a}$ as yelow crystals in $10 \%$ and $22 \%$ yields, respectively (Scheme 3a). The reaction of $\mathbf{1 b}$ with $\alpha, \alpha^{6}$-dibromo-o-xylylene ${ }^{[12]}$ generated by reductive debromination of $\alpha, \alpha, \alpha^{6}, \alpha^{6}$-tetrabromo-o-xylene 11 with potassium iodide produced $\mathbf{4 b}$ as stable orange crystals in $25 \%$ yield. ${ }^{[13]}$ The reaction using 2,3-bis(dibromomethyl)naphthalene $\mathbf{1 2}^{[14]}$ also afforded $\mathbf{4 b}$ as stable organge crystals in $5 \%$ yield (Scheme $3 \mathrm{~b}$ ).

The relatively low yields of the products would be ascribed to the thermal lability of the AIs as the starting materials, because thermal treatment at around the melting points readily converted the AIs into insoluble polymeric materials. Actually, after the reactions, $\mathbf{1 a}$ and $\mathbf{1} \mathbf{b}$ disappeared completely. 


\section{X-ray crystallographic analysis of $3 a$ and $4 b$}

Good single crystals of $\mathbf{3 a}$ and $\mathbf{4 b}$ for the X-ray analysis were collected from toluene/hexane solutions. Both the compounds crystalize with triclinic and belong to a $P-1$ space group. The molecular structures and molecular packing modes of $\mathbf{3 a}$ and $\mathbf{4 b}$ are disclosed in Figures 1 and 2, respectively. The FI skeleton of 3a possesses high planarity. Four phenyl groups are highly twisted from the FI plane with $67.2,63.6,71.1$ and $86.7^{\circ}$, respectively

(Figures 1a and 1b). Thus, the conjugation between the FI unit and each phenyl group would be highly retarded in the ground state. The molecules stack with a head-to-tail manner to from a dimer structure (Figure 1c), in which the closed $\pi$ - $\pi$ distance was $3.54 \AA$. The dimers form a one-dimensional slipped- $\pi$-stack columnar structure.

The $\pi$-skeleton of $\mathbf{4 b}$ possesses high planarity despite slightly curved with $8.17^{\circ}$ (Figures $2 \mathrm{a}$ and $2 \mathrm{~b}$ ). The molecules stack with a head-to-tail manner and form a one-dimensional slipped- $\pi$-stack columnar structure. The convex surfaces of the molecules are almost perfectly overlapped each other with $3.30 \AA$ of the closed $\pi-\pi$ distance between stacked BFI planes. On the other hand, the concave surfaces are slipped and stacked with the naphthalimide units.

\footnotetext{
$<$ Figures 1 and $2>$
}

\section{UV/Vis and fluorescence spectra}

UV/Vis and fluorescence spectra of 1a, 2a, 3a, $\mathbf{4 b}$, and $\mathbf{5 b}$ in $\mathrm{CH}_{2} \mathrm{Cl}_{2}$ were shown in Figure 3. The spectral data are summarized in Table 1. The absorption maxima $\left(\lambda_{\mathrm{ABS}}\right)$ of these compounds cause bathochromic shift with the extension of core $\pi$-systems. Actually, the $\lambda_{\mathrm{ABS}}$ of $\mathbf{1 a}(374 \mathrm{~nm})$ is the shortest and $\mathbf{5 b}(511 \mathrm{~nm})$ is the longest among these compounds. In the case of $\mathbf{2 a}$ and $\mathbf{3 a}$, the presence of the two or four phenyl groups cause little difference in the absorption spectra (both $\lambda_{\mathrm{ABS}}$ values are $422 \mathrm{~nm}$ ). Their short-wavelength-absorptions around 
$370-460 \mathrm{~nm}$ should be due to retardation of the $\pi$-conjugations by highly twisting structures of the molecules, as it was expected from the molecular structure of 3a. On the other hand, the fluorescence maxima $\left(\lambda_{\mathrm{EM}}\right)$ of these compounds in $\mathrm{CH}_{2} \mathrm{Cl}_{2}$ show the different order from the $\lambda_{\mathrm{ABS}}$ values; the $\lambda_{\mathrm{EM}}$ values of $\mathbf{2 a}$ and $\mathbf{3 a}$ are longer than that of $\mathbf{4 b}$. Thus, the Stokes shift of $\mathbf{2 a}\left(4100 \mathrm{~cm}^{-1}\right)$ and $\mathbf{3 a}\left(5080 \mathrm{~cm}^{-1}\right)$ are considerably larger than those of $\mathbf{4 b}$ $\left(1500 \mathrm{~cm}^{-1}\right)$ and $\mathbf{5 b}\left(2100 \mathrm{~cm}^{-1}\right)$. Moreover, the fluorescence quantum yields $\left(\Phi_{\mathrm{SL}}\right)$ of $\mathbf{2 a}$ and $\mathbf{3 a}$ in $\mathrm{CH}_{2} \mathrm{Cl}_{2}$ are remarkably low (0.01-0.02). These results suggest that $\pi$-conjugation of $\mathbf{2 a}$ and $\mathbf{3 a}$ in the excited states would be partially extended toward their phenyl groups by relaxation of the highly twisted structures. Moreover, the rotatory motion of the phenyl groups would accelerate a non-radiative process in the excited states, because the known FI derivatives with phenyl substituents at 7 and 10 positions show low $\Phi_{\mathrm{SL}}$ values. ${ }^{[5]}$ On the other hand, the small Stokes shifts and the relatively large $\Phi_{\mathrm{SL}}$ values of $\mathbf{4} \mathbf{b}$ and $\mathbf{5 b}$ indicate the rigid conformation of $\pi$-systems of these compounds.

$<$ Figure 3 $>$

$<$ Table 1>

\section{Self-aggregation behavior of $4 \mathrm{~b}$ and $5 \mathrm{~b}$}

It became evident during routine characterization of $\mathbf{4 b}$ and $\mathbf{5 b}$ with ${ }^{1} \mathrm{H}-\mathrm{NMR}$ spectroscopy in $\mathrm{CDCl}_{3}$ that their aromatic chemical shifts were dependent on the concentration. As increasing the concentration, the chemical shifts of the aromatic protons of $\mathbf{4 b}$ and $\mathbf{5 b}$ undergo a pronounced high-field shift (Figures $4 \mathrm{a}$ and $\mathrm{S} 1$ in the Supporting Information). These observations suggest that $\mathbf{4 b}$ and $\mathbf{5 b}$ self-associate in $\mathrm{CDCl}_{3}$ with $\pi-\pi$ stacking, and the up-field shift of aromatic protons would be attributed to the influence of the ring current from the neighboring molecule. Because of the large high-field shift ( $>1 \mathrm{ppm})$, it's probably fair to say that indefinite self-association is actually the more appropriate interpretation. Assuming a monomer-oligomer equilibrium, ${ }^{[15]}$ the association 
constants $\left(K_{\mathrm{a}}\right)$ of $\mathbf{4 b}$ and $\mathbf{5 b}$ at $20^{\circ} \mathrm{C}$ were determined to be $11.8 \pm 36.5$ and $13.1 \pm 3.2 \mathrm{M}^{-1}$ (Figures S2-S4).

Under high concentration, however, fluorescence of $\mathbf{4 b}$ and $\mathbf{5 b}$ was almost quenched. Thus, the aggregation-induced-quenching occurred in these compounds (Figure S5).

$<$ Figure 4>

\section{Solvatofluorochromism}

The compounds $\mathbf{4 b}$ and $\mathbf{5 b}$ also display moderate and remarkable solvatofluorochromism in various solvents under dilution conditions (ca. $10^{-5} \mathrm{M}$ ), although the fluorescence colors of $\mathbf{2 a}$ and $\mathbf{3 a}$ are almost independent upon the solvent polarities. The $\lambda_{\mathrm{ABS}}$ values of $\mathbf{4} \mathbf{b}$ and $\mathbf{5 b}$ are only slightly affected by solvent polarity $\left(\Delta \lambda_{\mathrm{ABS}}<10 \mathrm{~nm}\right.$,

Figure S6). The $\lambda_{\mathrm{EM}}$ of $\mathbf{4 b}$ is $452 \mathrm{~nm}$ in cyclohexane, $495 \mathrm{~nm}$ in $\mathrm{CH}_{2} \mathrm{Cl}_{2}$ and $518 \mathrm{~nm}$ in $\mathrm{CH}_{3} \mathrm{OH}\left(\mathbf{4 b}: \Delta \lambda_{\mathrm{EM}}=67 \mathrm{~nm}\right.$, Figure S7). From the images shown in Figure 5, the fluorescence colors of $\mathbf{5 b}$ cover blue-green to red range $\left(\Delta \lambda_{\mathrm{EM}}\right.$ $=116 \mathrm{~nm}$ ). Specifically, the $\lambda_{\mathrm{EM}}$ of $\mathbf{5 b}$ is $507 \mathrm{~nm}$ in cyclohexane, $535 \mathrm{~nm}$ in toluene, $572 \mathrm{~nm}$ in $\mathrm{CH}_{2} \mathrm{Cl}_{2}, 593 \mathrm{~nm}$ in $\mathrm{CH}_{3} \mathrm{CN}$, and $623 \mathrm{~nm}$ in $\mathrm{CH}_{3} \mathrm{OH}$. Only in cyclohexane does the emission spectrum of $\mathbf{5 b}$ become the mirror image of its absorption spectrum. The solvation relaxation of the singlet excited state of $\mathbf{5 b}$ does not occur in cyclohexane while it does occur in other solvents.

$<$ Figure 5 $>$

Further information regarding the solvent sensitivity of the absorption and emission spectra of $\mathbf{4} \mathbf{b}$ and $\mathbf{5 b}$ was obtained from the Lippert-Mataga plots (Figure 6a). ${ }^{[16]}$ The Lippert-Mataga equation ${ }^{[17]}$ can be used to correlate the energy difference between absorption and emission, also known as Stokes' shift $\left(\Delta_{\mathrm{SS}}\right)$, with solvent polarity represented by $\Delta \mathrm{f}^{[18]}$.

The Lippert-Mataga equation is as follow: 
$<$ Equation (1) $>$

where $v_{\mathrm{abs}}$ and $v_{\mathrm{em}}$ are the wavenumbers $\left(\mathrm{cm}^{-1}\right)$ corresponding to the absorption and the emission, respectively, $\mathrm{h}$ is Planck's constant, $\mathrm{c}$ is the speed of light, and a is the Onsager radius of the solvent cavity in which the fluorophore resides. The dipole moment differences between the excited and the ground state $(\Delta \mu)$ values were determined to be $10.8 \mathrm{D}$ for $\mathbf{4 b}$, and $16.0 \mathrm{D}$ for $\mathbf{5 b}$ (see the SI), which reflects a highly polarized excited-state. These values are in the range of those reported for solvatofluorochromic dyes $(3-20 \mathrm{D}) \cdot{ }^{[19]}$ Moreover, a good linear correlation also exists between the $\lambda_{\mathrm{EM}}$ of $\mathbf{4 b}$ and $\mathbf{5 b}$, and the solvent polarity parameter $E_{\mathrm{T}}(30)$ (Figures 6b). ${ }^{[20]}$ These results clearly confirm the ICT nature of the emission of $\mathbf{4 b}$ and $\mathbf{5 b}$.

$<$ Figure 6>

\section{Electrochemical properties and DFT calculations.}

The cyclic voltammograms (CV) of $\pi$-extended FI derivatives were measured in $\mathrm{CH}_{2} \mathrm{Cl}_{2}$ in the presence of $n-\mathrm{Bu}_{4} \mathrm{NClO}_{4}(0.1 \mathrm{M})$ as an electrolyte using $\mathrm{Fc} / \mathrm{Fc}^{+}$as an internal standard (Table 2). Two reversible one-electron reduction waves were observed at -1.01 and $-1.41 \mathrm{~V}$ for $\mathbf{2 a},-1.10$ and $-1.51 \mathrm{~V}$ for $\mathbf{3 a},-0.97$ and $-1.38 \mathrm{~V}$ for $\mathbf{4 b}$, and -0.97 and $-1.37 \mathrm{~V}$ for $\mathbf{5 b}$ (Table 1 and Figure $\mathrm{S} 7$ ), respectively. The high reversibility of each $\mathrm{CV}$ indicates the high stability of the corresponding radical anions and dianions of the $\pi$-extended FIs. On the other hand, no oxidation potentials of all the imides were observed in the measurable range $(<+1.3 \mathrm{~V})$. The reduction potentials indicate highly electron-accepting abilities of these imide derivatives. However, these values are little sensitive to $\pi$-extension of the compounds.

$<$ Figure $7>$

To investigate the relationship between optical and electronic properties, the DFT calculations with the $N$-methyl 
$\pi$-extended FI derivatives $\mathbf{2 c - 5 c}$ were performed by using B3LYP/6-31G(d) level of theory embedded in the Gaussian 09 software package. ${ }^{[11]}$ For simplicity, $\mathbf{2 c - 5 c}$ were used as models for the calculations. Figure 7 illustrates the HOMO and LUMO coefficients on the optimized conformations of $\mathbf{2 c - 5}$. The HOMO and LUMO coefficients of $\mathbf{2} \mathbf{c}$ and $\mathbf{3 c}$ extend all the molecules without the carbons of phenyl substituents, owing to large torsion of the phenyl ring planes. The phenyl groups in the calculated geometries of $\mathbf{3 c}$ appear to be substantially more twisted than in the crystal structure of 3a (Figure 1). The crystal packing forces would cause the somewhat conformational planarization of the molecules. The calculated HOMO and LUMO energies ( $E_{\mathrm{HOMO}}$ and $\left.E_{\mathrm{LUMO}}\right)$, and calculated and observed energy gaps $\left(\Delta E_{\mathrm{cal}}\right.$ and $\left.\Delta E_{\mathrm{obs}}\right)$ of the $\pi$-extended FI derivatives are shown in Table 2 . The $E_{\mathrm{LUMO}}$ levels of $\mathbf{2} \mathbf{c}-\mathbf{5 c}$ are almost constant. The predictions are in good agreement with the synchronized reduction potentials of $\mathbf{2 a}, \mathbf{3 a}, \mathbf{4} \mathbf{b}$ and $\mathbf{5 b}$. Thus, the variation of $\Delta E_{\mathrm{cal}}$ and $\Delta E_{\mathrm{ob}}$ are mainly ascribed to the changes of $E_{\mathrm{HOMO}}$. The $E_{\mathrm{HOMO}}$ values increase with the extension of $\pi$-conjugation. The HOMO coefficient of $\mathbf{5} \mathbf{c}$ is found to be located on the anthracene moiety, while the LUMO coefficient is mainly located on the naphthalene imide moiety (Figure 7). The high spatial separation between the HOMO and LUMO coefficients in the molecule indicates that the ground-to-excited state transition should have intramolecular charge transfer (ICT) character. Thus, the structural features of $\mathbf{5 b}$, correctly classified as having a "push-pull" structure, ${ }^{[2]}$ are consistent with its remarkable solvatochromic emission properties. Moreover, the weak solvatochromic properties of $\mathbf{2 a}$ and 3a are probably due to poor spatial separation between the HOMO and LUMO in the molecules. Moreover, the calculations indicate that $\pi$-extended FI derivatives possess considerably high dipole moments ( $>5.2 \mathrm{D})$. Among them, the dipole moment of $\mathbf{5 b}(6.18 \mathrm{D})$ is the highest. As mentioned before, acenaphtho[1,2-j]fluoranthene imide 6b with relatively high dipole moment $(3.0 \mathrm{D})$ exhibits self-aggregation behavior in $\mathrm{CDCl}_{3}{ }^{[8]}$ According to 
crystallographic analysis of $\mathbf{3 a}$ and $\mathbf{4 b}$, these compounds exist in a head-to-tail dimer form in the solid states.

However, there is no proof that 3a with high dipole moment $(5.76 \mathrm{D})$ aggregates in $\mathrm{CDCl}_{3}$. Owing to the large high-field shift (>1 ppm), we adopted the indefinite self-association model to determine the $K_{\mathrm{a}}$ value of $\mathbf{4 d}$ and $\mathbf{5 b}$ as mentioned above. The large aromatic surfaces of $\mathbf{4 d}$ and $\mathbf{5 b}$ together with $\mathbf{6 b}$ would play an important role in the formation of oligomeric aggregates in $\mathrm{CDCl}_{3}$.

$<$ Table 2>

\section{Conclusion}

The Diels-Alder reactions of the AI derivatives 1 with some dienes produced a series of $\pi$-extended FI derivatives

2a, 3a, 4b and 5b. An X-ray crystallographic analysis of 3a reveal that the FI moiety has a planar structure, and

the phenyl substituents are highly twisted from the FI plane. The analysis of $\mathbf{4 b}$ reveals that the $\pi$-unit has a

slightly bent structure. The molecules of $\mathbf{3 a}$ and $\mathbf{4 b}$ stack with a head-to-tail manner, and form a columnar

stacking in the crystals. The $\lambda_{\mathrm{ABS}}$ values of $\pi$-extended FI derivatives cause a bathochromic shift with the

extension of core $\pi$-systems, while the $\lambda_{\mathrm{EM}}$ values of $\mathbf{2 a}$ and $\mathbf{3 a}$ are longer than that of $\mathbf{4 b}$. The presence of two or

four phenyl substituents of $\mathbf{2 a}$ and $\mathbf{3 a}$ has little effect on the absorption spectra, due to retardation of the

$\pi$-conjugations by highly twisting structures of the molecules. The $\pi$-conjugation of $\mathbf{2 a}$ and $\mathbf{3 a}$ in the excited states

would be fairly extended toward their phenyl substituents by relaxation of the highly twisted structures. On the

other hand, the relatively large $\Phi_{\mathrm{SL}}$ values and the small Stokes shifts of $\mathbf{4 b}$ and $\mathbf{5 b}$ indicate the rigid conformation

of these compounds. The fluorophore $4 \mathbf{b}$ and $\mathbf{5 b}$ are found to display both solvatofluorochromism (4b for $\Delta \lambda_{\mathrm{EM}}=$

$67 \mathrm{~nm}$ and $\mathbf{5 b}$ for $\Delta \lambda_{\mathrm{EM}}=116 \mathrm{~nm}$ ) and self-aggregation in $\mathrm{CDCl}_{3}$ solutions. Their electrochemical measurements 
using CV clearly indicate low $E_{\mathrm{LUMO}}$ of the FIs and high stability of the anionic species. The electrochemical properties are in good agreement with the results of the DFT calculations. Especially, the DFT calculations with model compounds of $\mathbf{5 b}$ revealed the existence of excited-state ICT between the donor anthracene and acceptor naphthalimide moieties. Further studies on the applicability of $\pi$-extended FI derivatives to the design of other $\pi$-conjugated systems, as well as their potential use in organic optoelectronic materials, are underway.

\section{Experimental Section}

\section{General:}

All reactions of air- or moisture-sensitive compounds were carried out in a dry reaction vessel under a positive pressure of nitrogen. Air- and moisture-sensitive liquids and solutions were transferred via syringe. Analytical thin-layer chromatography was performed using glass plates pre-coated with Merck Art. 7730 Kiesel-gel 60 GF-254. Thin layer chromatography plates were visualized by exposure to UV light. Organic solutions were concentrated by using rotary evaporation at ca. 15 Torr obtained with a diaphragm pump. Column chromatography was performed with Merck Kiesel-gel 60. All reagents were commercially available and used without further purification unless otherwise noted. THF was purchased from Wako Chemical Co. and distilled from lithium aluminum hydride at 760 Torr under a nitrogen atmosphere before use. Melting points were recorded on a Yanaco MP-S3 apparatus and reported uncorrected. FAB and high-resolution mass spectra were measured on

a JEOL JMS-700. ${ }^{1} \mathrm{H}$ and ${ }^{13} \mathrm{C}$ NMR spectra were recorded on a Bruker-Biospin DRX-500 spectrometer. ${ }^{1} \mathrm{H}$ NMR spectral data for the compounds were measured at $20^{\circ} \mathrm{C}$. IR spectra were obtained using a JASCO FTIR-4100 spectrometer. Electronic (UV-Vis) and fluorescence spectra in solution were recorded with a JASCO V650 and a 
SHIMADZU RF-5300PC spectrophotometers, respectively. Quantum yields for solution state fluorescence $\left(\Phi_{\mathrm{SN}}\right)$ were determined using 9,10-diphenylanthracene $\left(\Phi_{\mathrm{SN}}=0.86\right)^{[21]}$ in $\mathrm{CH}_{2} \mathrm{Cl}_{2}$ as an actinometer. DFT calculations were carried out by using the B3LYP/6-31G(d) method with the Gaussian 09 program package. ${ }^{[9]}$

Acenaphthene-5,6-dicarboxyic anhydride 7 was prepared from acenaphthene using reported procedure. ${ }^{[10]}$

Synthesis

$N$-(2-Ethylhexyl)-acenaphthene-5,6-dicarboxyimide $(\mathbf{8 a})^{[10]}$

A solution of $7(3.36 \mathrm{~g}, 15 \mathrm{mmol})$ and 2-ethylhexylamine $(3.7 \mathrm{~mL}, 23 \mathrm{mmol})$ in ethanol $(80 \mathrm{~mL})$ was heated at reflux for $12 \mathrm{~h}$. After cooling at $\mathrm{rt}$, the solvent was evaporated under reduced pressure. The resulting solid was recrystallized from hexane to give 8a as colorless crystals in $80 \%$ yield $(4.01 \mathrm{~g}, 12.0 \mathrm{mmol})$. Mp: $102-104{ }^{\circ} \mathrm{C}$ (ref. 10: $\left.142-143{ }^{\circ} \mathrm{C}\right) ;{ }^{1} \mathrm{H}$ NMR $\left(500 \mathrm{MHz}, \mathrm{CDCl}_{3}\right) \delta 0.92(\mathrm{t}, J=7.4 \mathrm{~Hz}, 3 \mathrm{H}), 0.87(\mathrm{t}, J=7.4 \mathrm{~Hz}, 3 \mathrm{H}), 1.29-1.39(\mathrm{~m}$, $8 \mathrm{H}), 1.91-1.95(\mathrm{~m}, 1 \mathrm{H}), 3.56(\mathrm{~s}, 4 \mathrm{H}), 4.07-4.16(\mathrm{~m}, 2 \mathrm{H}), 7.55(\mathrm{~d}, J=7.4 \mathrm{~Hz}, 2 \mathrm{H}), 8.48(\mathrm{~d}, J=7.4 \mathrm{~Hz}, 2 \mathrm{H}) ;{ }^{13} \mathrm{C}$ $\operatorname{NMR}\left(125 \mathrm{MHz}, \mathrm{CDCl}_{3}\right): \delta 10.74,14.16,23.12,24.09,28.80,30.79,31.70,38.00,44.01,119.23,120.92,126.44$, $132.79,137.81,153.71,164.83$.

$N$-(n-Octyl)-acenaphthene-5,6-dicarboxyimide (8b)

A solution of acenaphthene-5,6-dicarboxylic anhydride $7(897 \mathrm{mg}, 4.0 \mathrm{mmol})$ and $n$-octylamine $(0.83 \mathrm{~mL}, 5.0$ mmol) in ethanol $(70 \mathrm{~mL})$ was heated at reflux for $12 \mathrm{~h}$. After cooling at $\mathrm{rt}$, the solvent was evaporated under reduced pressure. The resulting solid was recrystallized from hexane to give $\mathbf{8 b}$ as colorless crystals in $70 \%$ yield (938 mg, $2.8 \mathrm{mmol}) . \mathrm{Mp}: 94-96{ }^{\circ} \mathrm{C} ;{ }^{1} \mathrm{H}$ NMR $\left(500 \mathrm{MHz}, \mathrm{CDCl}_{3}\right): \delta 0.90(\mathrm{t}, J=7.4 \mathrm{~Hz}, 3 \mathrm{H}), 1.27-1.43(\mathrm{~m}, 10 \mathrm{H})$, $1.70-1.73(\mathrm{~m}, 2 \mathrm{H}), 3.54(\mathrm{~s}, 4 \mathrm{H}), 4.16(\mathrm{t}, J=7.7 \mathrm{~Hz}, 2 \mathrm{H}), 7.52(\mathrm{~d}, J=7.3 \mathrm{~Hz}, 2 \mathrm{H}), 8.46(\mathrm{~d}, J=7.3 \mathrm{~Hz}, 2 \mathrm{H}) ;{ }^{13} \mathrm{C}$ $\operatorname{NMR}\left(125 \mathrm{MHz}, \mathrm{CDCl}_{3}\right): \delta 14.14,22.68,27.22,28.29,29.28,29.42,31.68,31.86,40.38,119.20,120.86,126.33$, 
132.66, 137.73, 153.71, 164.37; IR (KBr): v 2952 (m), 2934 (m), 2919 (m), 2856 (m), 1690 (s), 1660 (s), 1628

(m), 1460 (m), 1415 (m), 1341 (m), 1236 (m), $1073(\mathrm{~m}), 771(\mathrm{~m}) \mathrm{cm}^{-1}$; HRMS (FAB, NBA) m/z: calculated for

$\left[\mathrm{C}_{22} \mathrm{H}_{26} \mathrm{NO}_{2}\right], 335.1965$; found: 336.1959 .

N-(2-Ethylhexyl)acenaphthylene-5,6-dicarboxyimide (1a)

To a solution of $8 \mathrm{a}(4.0 \mathrm{~g}, 12 \mathrm{mmol})$ and NBS $(2.4 \mathrm{~g}, 13 \mathrm{mmol})$ in carbon tetrachloride $(80 \mathrm{~mL})$ was added

benzoyl peroxide $(300 \mathrm{mg})$. The reaction mixture was heated at reflux for $1 \mathrm{~h}$. After cooling at $\mathrm{rt}$, formed

succinimide was filtered off. The filtrate was concentrated under reduced pressure to give

$N$-(2-ethylhexyl)-1-bromoacenphthene-5,6-dicarboxyimide (3.0 g, $7.2 \mathrm{mmol}$ ) as pale yellow solid in 60\% yield.

Mp: $112-114{ }^{\circ} \mathrm{C} ;{ }^{1} \mathrm{H} \mathrm{NMR}\left(500 \mathrm{MHz}, \mathrm{CDCl}_{3}\right) \delta 0.87(\mathrm{t}, J=6.8 \mathrm{~Hz}, 3 \mathrm{H}), 0.92(\mathrm{t}, J=7.3 \mathrm{~Hz}, 3 \mathrm{H}), 1.29-1.40(\mathrm{~m}$,

8H), 1.93-1.91 (m, 1H), $3.92(\mathrm{~d}, J=19.2 \mathrm{~Hz}, 1 \mathrm{H}), 4.08-4.17(\mathrm{~m}, 2 \mathrm{H}), 4.29(\mathrm{dd}, J=6.8,19.2 \mathrm{~Hz}, 1 \mathrm{H}), 5.92(\mathrm{~d}, J$

$=6.8 \mathrm{~Hz}, 2 \mathrm{H}), 7.59(\mathrm{~d}, J=7.3 \mathrm{~Hz}, 1 \mathrm{H}), 7.75(\mathrm{~d}, J=7.4 \mathrm{~Hz}, 1 \mathrm{H}), 8.53(\mathrm{~d}, J=7.3 \mathrm{~Hz}, 1 \mathrm{H}), 8.57(\mathrm{~d}, J=7.4 \mathrm{~Hz}$,

1H); IR (KBr): v 2959 (m), 2927 (m), 2857 (m), 1700 (s), $1656(\mathrm{~s}), 1630(\mathrm{~m}), 1456(\mathrm{~m}), 1418(\mathrm{~m}), 1334(\mathrm{~m})$,

1234 (m), $1174(\mathrm{~m}), 755$ (m) $\mathrm{cm}^{-1}$; HRMS (FAB, NBA) m/z: calculated for $\left[\mathrm{C}_{22} \mathrm{H}_{25} \mathrm{BrNO}_{2}\right]$, 414.1070; found:

414.1065. A solution of $N$-(2-ethylhexyl)-1-bromoacenphthene-5,6-dicarboxylimide (2.98 g, $7.2 \mathrm{mmol}$ ) and

lithium bromide $(1.88 \mathrm{~g}, 22 \mathrm{mmol})$ in $\mathrm{DMF}(40 \mathrm{~mL})$ was heated at $120^{\circ} \mathrm{C}$ for $2 \mathrm{~h}$. After cooling at $0{ }^{\circ} \mathrm{C}$ in an ice

bath, the reaction mixture was poured into ice water $(500 \mathrm{~mL})$. Precipitate was filtered, dried under reduced

pressure, and recrystallized from methanol to give $1 \mathrm{a}(2.11 \mathrm{~g}, 6.3 \mathrm{mmol})$ as an orange solid in $88 \%$ yield. Mp:

$115-117^{\circ} \mathrm{C} ;{ }^{1} \mathrm{H} \mathrm{NMR}\left(500 \mathrm{MHz}, \mathrm{CDCl}_{3}\right) \delta 0.87(\mathrm{t}, J=7.1 \mathrm{~Hz}, 3 \mathrm{H}), 0.92(\mathrm{t}, J=7.4 \mathrm{~Hz}, 3 \mathrm{H}), 1.30-1.40(\mathrm{~m}, 8 \mathrm{H})$,

1.88-1.91 (m, 1H), 4.03-4.12 (m, 2H), $7.08(\mathrm{~s}, 2 \mathrm{H}), 7.72(\mathrm{~d}, J=7.1 \mathrm{~Hz}, 2 \mathrm{H}), 8.32(\mathrm{~d}, J=7.1 \mathrm{~Hz}, 2 \mathrm{H}) ;{ }^{13} \mathrm{C}$ NMR

(125 MHz, $\left.\mathrm{CDCl}_{3}\right): \delta 10,70,14.11,23.09,24.07,28.75,30.77,38.29,43.97,122.89,123.34,125.04,127.51$, 
131.68, 132.89, 144.35, 164.35; IR (KBr): v 2954 (m), 2925 (m), 2871 (m), 2856 (m), 1703 (s), $1658(\mathrm{~s}), 1619$

(m), $1456(\mathrm{~m}), 1346(\mathrm{~m}), 1327$ (m), 1229 (s), $1173(\mathrm{~m}), 718(\mathrm{~m}) \mathrm{cm}^{-1}$; HRMS (FAB, NBA) m/z: calculated for

$\left[\mathrm{C}_{22} \mathrm{H}_{24} \mathrm{NO}_{2}\right], 334.1808$; found: 334.1804 .

N-(n-Octyl)-acenaphthylene-5,6-dicarboxyimides (1b)

A solution of $\mathbf{8 b}(938 \mathrm{mg}, 2.8 \mathrm{mmol})$, NBS (534 mg, $3.0 \mathrm{mmol})$ and benzoyl peroxide $(70 \mathrm{mg})$ in carbon

tetrachloride $(30 \mathrm{~mL})$ was heated at reflux for $1 \mathrm{~h}$. After cooling at $\mathrm{rt}$, formed succinimide was filtered off. The

filtrate was concentrated under reduced pressure to give $N$-(n-octyl)-1-bromoacenphthene-5,6-dicarboxyimide

(735 mg, $1.9 \mathrm{mmol}$ ) as pale yellow solids in $68 \%$ yield. Mp: $122-124{ }^{\circ} \mathrm{C} ;{ }^{1} \mathrm{H}$ NMR $\left(500 \mathrm{MHz}, \mathrm{CDCl}_{3}\right) \delta 0.87(\mathrm{t}, J$

$=7.1 \mathrm{~Hz}, 3 \mathrm{H}), 1.28-1.42(\mathrm{~m}, 10 \mathrm{H}), 1.77-1.79(\mathrm{~m}, 2 \mathrm{H}), 3.92(\mathrm{~d}, J=19.5 \mathrm{~Hz}, 1 \mathrm{H}), 4.15-4.18(\mathrm{~m}, 2 \mathrm{H}), 4.28(\mathrm{dd}, J$

$=7.4,19.5 \mathrm{~Hz}, 1 \mathrm{H}), 5.92(\mathrm{~d}, J=7.4 \mathrm{~Hz}, 2 \mathrm{H}), 7.60(\mathrm{~d}, J=7.3 \mathrm{~Hz}, 1 \mathrm{H}), 7.78(\mathrm{~d}, J=7.3 \mathrm{~Hz}, 1 \mathrm{H}), 8.55(\mathrm{~d}, J=7.3$

Hz, 1H), 8.58 (d, $J=7.3 \mathrm{~Hz}, 1 \mathrm{H}) ; \mathrm{IR}(\mathrm{KBr}): v 2952$ (m), 2922 (m), 2853 (m), 1699 (s), 1659 (s), 1631 (m), 1469

(m), $1455(\mathrm{~m}), 1417(\mathrm{~m}), 1335(\mathrm{~m}), 1236(\mathrm{~m}), 864(\mathrm{~m}), 757(\mathrm{~m}) \mathrm{cm}^{-1}$; HRMS (FAB, NBA) $m / z$ : calculated for

$\left[\mathrm{C}_{22} \mathrm{H}_{25} \mathrm{BrNO}_{2}\right], 414.1070$; found: 414.1072 . Without further purification, a solution of crude

$N$-(n-octyl)-1-bromoacenphthene-5,6-dicarboxylimide (785 mg, $1.9 \mathrm{mmol})$ and lithium bromide (492 $\mathrm{mg}, 5.7$

mmol) in DMF $(10 \mathrm{~mL})$ was heated at $120^{\circ} \mathrm{C}$ for $2 \mathrm{~h}$. After cooling at $0{ }^{\circ} \mathrm{C}$ in an ice bath, the reaction mixture

was poured into ice water $(200 \mathrm{~mL})$. Precipitate was filtered, dried under reduced pressure, and recrystallized

from methanol to give $\mathbf{1 b}(441 \mathrm{mg}, 1.32 \mathrm{mmol})$ as orange solids in $70 \%$ yield. Mp: $114-116{ }^{\circ} \mathrm{C} ;{ }^{1} \mathrm{H} \mathrm{NMR}$

$\left(500 \mathrm{MHz}, \mathrm{CDCl}_{3}\right) \delta 0.90(\mathrm{t}, J=7.4 \mathrm{~Hz}, 3 \mathrm{H}), 1.27-1.41(\mathrm{~m}, 10 \mathrm{H}), 1.69-1.71(\mathrm{~m}, 2 \mathrm{H}), 4.10-4.13(\mathrm{~m}, 2 \mathrm{H}), 7.06(\mathrm{~s}$,

2H), $7.70(\mathrm{~d}, J=7.1 \mathrm{~Hz}, 2 \mathrm{H}), 8.31(\mathrm{~d}, J=7.1 \mathrm{~Hz}, 2 \mathrm{H}) ;{ }^{13} \mathrm{C} \mathrm{NMR}\left(125 \mathrm{MHz}, \mathrm{CDCl}_{3}\right): \delta 14.14,22.68,27.17,28.58$,

29.27, 29.39, 31.85, 40.36, 122.85, 123.24, 125.01, 127.47, 131.59, 132.90, 144.34, 163.93; IR (KBr): v 2954 (m), 
2925 (m), 2851 (m), 1703 (s), $1659(\mathrm{~s}), 1619(\mathrm{~m}), 1456(\mathrm{~m}), 1345$ (m), $1330(\mathrm{~m}), 1232(\mathrm{~m}), 1163(\mathrm{~m}), 1110(\mathrm{~m})$

$\mathrm{cm}^{-1}$; HRMS (FAB, NBA) $m / z$ : calculated for $\left[\mathrm{C}_{22} \mathrm{H}_{24} \mathrm{NO}_{2}\right]$, 334.1808; found: 334.1804 .

DPFI (2a)

A solution of 1a (487 mg, $1.46 \mathrm{mmol})$ and 2,5-diphenylthiophene 1,1-dioxide 9 (390 mg, $1.46 \mathrm{mmol})$ in $o$-xylene $(15 \mathrm{~mL})$ was heated at reflux for five days. After cooling at $\mathrm{rt}$, the reaction mixture was charged on silica gel column chromatography directly to give a crude product from toluene elusion. The product was recrystallized from toluene-hexane (1:1) to afford $\mathbf{2 a}(82.0 \mathrm{mg}, 0.15 \mathrm{mmol})$ as yellow crystals in $10 \%$ yield. ${ }^{1} \mathrm{H} \mathrm{NMR}\left(\mathrm{CDCl}_{3}\right.$, $500 \mathrm{MHz}): \mathrm{Mp}:\left(242-243{ }^{\circ} \mathrm{C}\right) ; \delta 0.85(\mathrm{t}, J=6.9 \mathrm{~Hz}, 3 \mathrm{H}), 0.90(\mathrm{t}, J=7.4 \mathrm{~Hz}, 3 \mathrm{H}), 1.27-1.36(\mathrm{~m}, 8 \mathrm{H}), 1.87-1.89$ (m, 1H), 4.01-4.07 (m, 2H), $7.28(\mathrm{~d}, J=7.4 \mathrm{~Hz}, 2 \mathrm{H}), 7.31(\mathrm{~s}, 2 \mathrm{H}), 7.54-7.62(\mathrm{~m}, 10 \mathrm{H}), 8.19$ (d, $J=7.4 \mathrm{~Hz}, 2 \mathrm{H})$; ${ }^{13} \mathrm{C}$ NMR (125 MHz, $\left.\mathrm{CDCl}_{3}\right): \delta 10.65,14.06,23.05,24.00,28.66,30.67,38.06,43.92,121.95,123.41,125.03$, $128.37,128.70,128.91,131.03,131.70,131.90,137.30,139.62,139.64,141.80,164.22 ; \mathrm{IR}(\mathrm{KBr}): v 2956(\mathrm{~m})$, $2924(\mathrm{~m}), 2858(\mathrm{~m}), 2372(\mathrm{w}), 2319(\mathrm{w}), 1698$ (s), 1661 (s), $1636(\mathrm{~s}), 1450(\mathrm{~m}), 1338(\mathrm{~s}), 1235$ (s), $761(\mathrm{~s}), 701$ (s) $\mathrm{cm}^{-1}$; MS (EI) m/z $535\left(\mathrm{M}^{+}, 79\right), 423$ (100); HRMS (FAB, NBA) $m / z$ : calculated for $\left[\mathrm{C}_{38} \mathrm{H}_{33} \mathrm{NO}_{2}\right], 535.2513$; found: 535.2518 .

\section{TPFI (3a)}

A solution of 1a $(100 \mathrm{mg}, 0.30 \mathrm{mmol})$ and tetracyclone $10(115 \mathrm{mg}, 0.30 \mathrm{mmol})$ in $o$-xylene $(10 \mathrm{~mL})$ was heated at reflux for one day. After cooling at rt, the reaction mixture was charged on silica gel column chromatography directly to give a crude product from toluene elusion. The product was recrystallized from toluene-hexane (1:1) to afford 3a (45.0 mg, $0.065 \mathrm{mmol})$ as orange crystals in $22 \%$ yield. Mp: $281-282{ }^{\circ} \mathrm{C} ;{ }^{1} \mathrm{H} \mathrm{NMR}\left(\mathrm{CDCl}_{3}, 500 \mathrm{MHz}\right)$ : $\delta 0.85(\mathrm{t}, J=7.1 \mathrm{~Hz}, 3 \mathrm{H}), 0.89(\mathrm{t}, J=7.4 \mathrm{~Hz}, 3 \mathrm{H}), 1.26-1.35(\mathrm{~m}, 8 \mathrm{H}), 1.87(\mathrm{~m}, 1 \mathrm{H}), 4.03-4.06(\mathrm{~m}, 2 \mathrm{H}), 6.61(\mathrm{~d}, J$ 
$=7.4 \mathrm{~Hz}, 2 \mathrm{H}), 6.87-6.91(\mathrm{~m}, 10 \mathrm{H}), 7.27-7.30(\mathrm{~m}, 4 \mathrm{H}), 7.31-7.35(\mathrm{~m}, 6 \mathrm{H}), 8.13(\mathrm{~d}, J=7.4 \mathrm{~Hz}, 4 \mathrm{H}) ;{ }^{13} \mathrm{C} \mathrm{NMR}$

$\left(125 \mathrm{MHz}, \mathrm{CDCl}_{3}\right): \delta 10.66,14.08,23.07,24.00,28.66,30.67,38.07,43.92,121.78,123.58,124.87,125.82$,

$126.81,127.47,128.42,129.61,130.91,132.01,132.14,137.11,138.65,138.99,139.05,142.10,142.64,164.28$.

IR (KBr): v 3058 (m), $3028(\mathrm{~m}), 2958(\mathrm{~m}), 2926(\mathrm{~m}), 2858(\mathrm{~m}), 1702$ (s), $1665(\mathrm{~s}), 1653(\mathrm{~s}), 1453(\mathrm{~m}), 1334(\mathrm{~s})$,

1236 (s), $756(\mathrm{~m}), 698(\mathrm{~s}) \mathrm{cm}^{-1}$. MS (EI) m/z $687\left(\mathrm{M}^{+}, 100\right), 575$ (98); HRMS (FAB, NBA) m/z: calculated for

$\left[\mathrm{C}_{50} \mathrm{H}_{42} \mathrm{NO}_{2}\right], 688.3218$; found: 688.3214 .

\section{BFI (4b)}

A solution of $\mathbf{1 b}$ (167 mg, $0.50 \mathrm{mmol})$, 7,7,8,8-tetrabromo-o-xylene $11(210 \mathrm{mg}, 0.50 \mathrm{mmol})$ and potassium iodide

(536 mg, $3.23 \mathrm{mmol})$ in DMF $(5 \mathrm{~mL})$ was heated at $80^{\circ} \mathrm{C}$ for one day. After cooling at $\mathrm{rt}$, the reaction mixture

was quenched with water and extracted with toluene. The separated organic layer was washed with brine and dried

over anhydrous sodium sulfate. After removing the dry agent, the solvent was evaporated under reduced pressure.

The residue was purified by a silica gel column chromatography to give crude product from

dichloromethane-hexane (1:2) as an elution. The crude product was recrystallized from a dichloromethane-hexane

solution to give $4 \mathbf{b}(54.0 \mathrm{mg}, 0.125 \mathrm{mmol})$ as yellow needles in $25 \%$ yield. Mp: $174-175{ }^{\circ} \mathrm{C} ;{ }^{1} \mathrm{H} \mathrm{NMR}\left(\mathrm{CDCl}_{3}\right.$,

$500 \mathrm{MHz}): \delta 0.87(\mathrm{t}, J=6.9 \mathrm{~Hz}, 3 \mathrm{H}), 1.25-1.45(\mathrm{~m}, 10 \mathrm{H}), 1.70-1.73(\mathrm{~m}, 2 \mathrm{H}), 4.17(\mathrm{t}, J=7.7 \mathrm{~Hz}, 2 \mathrm{H}), 7.55(\mathrm{~m}$,

$\left.\mathrm{AA}^{\prime} X X^{\prime}, J_{\mathrm{AX}}=6.1 \mathrm{~Hz}, 2 \mathrm{H}\right), 7.55\left(\mathrm{~m}, \mathrm{AA}^{\prime} X X^{\prime}, J_{\mathrm{AX}}=6.1 \mathrm{~Hz}, 2 \mathrm{H}\right), 8.05(\mathrm{~d}, J=7.3 \mathrm{~Hz}, 2 \mathrm{H}), 8.28(\mathrm{~s}, 2 \mathrm{H}), 8.53(\mathrm{~d}$,

$J=7.3 \mathrm{~Hz}, 2 \mathrm{H}) .{ }^{13} \mathrm{C}$ NMR $\left(125 \mathrm{MHz}, \mathrm{CDCl}_{3}\right): \delta 14.11,22.65,27.18,28.41,29.25,29.38,31.83,40.42,119.81$,

$121.71,123.04,127.49,129.27,132.49,133.88,134.02,137.16,142.33,143.72,163.92$; IR (KBr): v 2926 (m),

$2848(\mathrm{~m}), 2361(\mathrm{~m}), 2343(\mathrm{~m}), 1698(\mathrm{~s}), 1664(\mathrm{~s}), 1639(\mathrm{~s}), 1460(\mathrm{~m}), 1332(\mathrm{~m}), 1234(\mathrm{~m}), 1065(\mathrm{~m}), 818(\mathrm{~s}), 743$

(s) $\mathrm{cm}^{-1}$. MS (EI) m/z $433\left(\mathrm{M}^{+}, 100\right)$; HRMS (FAB, N BA) $m / z$ : calculated for $\left[\mathrm{C}_{30} \mathrm{H}_{28} \mathrm{NO}_{2}\right], 434.2114$; found 
434.2113.

\section{$N F I(5 b)$}

A solution of $\mathbf{1 b}$ (167 mg, $0.50 \mathrm{mmol}), 2,3$-bis(dibromomethyl)naphthalene 12 (236 mg, $0.50 \mathrm{mmol}$ ) and sodium iodide (450 mg, $3.0 \mathrm{mmol})$ in DMF $(5 \mathrm{~mL})$ was heated at $80{ }^{\circ} \mathrm{C}$ for one day. After cooling at $\mathrm{rt}$, the reaction mixture was quenched with water and extracted with toluene. The separated organic layer was washed with brine and dried over anhydrous sodium sulfate. After removing the dry agent, the solvent was evaporated under reduced pressure. The residue was purified by a silica gel column chromatography to give crude product from dichloromethane-hexane (1:2) as an elution. The crude product was recrystallized from a dichloromethane-hexane solution to give $\mathbf{5 b}(9.0 \mathrm{mg}, 0.02 \mathrm{mmol})$ as orange needles in 5\% yield. Mp: $236-237{ }^{\circ} \mathrm{C} ;{ }^{1} \mathrm{H} \mathrm{NMR}\left(\mathrm{CDCl}_{3}, 500\right.$ MHz): $\delta 0.88(\mathrm{t}, J=6.8 \mathrm{~Hz}, 3 \mathrm{H}), 1.25-1.43(\mathrm{~m}, 10 \mathrm{H}), 1.69-1.72(\mathrm{~m}, 2 \mathrm{H}), 4.15(\mathrm{t}, J=7.5 \mathrm{~Hz}, 2 \mathrm{H}), 7.52-7.54(\mathrm{~m}$, $\left.\mathrm{AA}^{\prime} \mathrm{XX}^{\prime}, J_{\mathrm{AX}}=6.4 \mathrm{~Hz}, 2 \mathrm{H}\right), 7.99-8.01\left(\mathrm{~m}, \mathrm{AA}^{\prime} \mathrm{XX}^{\prime}, J_{\mathrm{AX}}=6.4 \mathrm{~Hz}, 2 \mathrm{H}\right), 8.04(\mathrm{~d}, J=7.3 \mathrm{~Hz}, 2 \mathrm{H}), 8.39(\mathrm{~s}, 2 \mathrm{H})$, 8.43 (s, 2H), 8.53 (d, J=7.3 Hz, 2H); IR (KBr): v 2952 (m), 2924 (m), 2853 (m), 2359 (m), 2337 (m), 1696 (s), 1660 (s), 1637 (s), 1455 (m), 1403 (m), 1358 (m), 1339 (m) cm² ; HRMS (FAB, NBA) m/z: calculated for $\left[\mathrm{C}_{34} \mathrm{H}_{30} \mathrm{NO}_{2}\right], 484.2278$; found 484.2280 . (A satisfactory ${ }^{13} \mathrm{C}-\mathrm{NMR}$ spectrum of $\mathbf{5 b}$ was not obtained even under high concentration $\left(2 \times 10^{-2} \mathrm{M}\right)$ probably due to self-aggregation of the compound.)

X-ray Crystallography

Single crystals of $\mathbf{3 a}$ and $\mathbf{4 b}$ for X-ray analysis were obtained by slow evaporation from a toluene/n-hexane (1:1) solutions. X-ray diffraction data were collected on a Rigaku Rapid Auto diffractometer with graphite-monochromated $\operatorname{MoKa}(\lambda=0.71070 \AA)$ radiation, and $\Phi$ and $\omega$ scans at a maximum $2 \theta$ value of 55.08.

The structures were solved by a direct method using SIR2004. ${ }^{[22]}$ All non-hydrogen atoms were refined 
anisotropically by full-matrix least-squares on $F^{2}$ using SHELXL97. ${ }^{[23]}$ Hydrogen atoms of $\mathbf{3 a}$ and $\mathbf{4 b}$ were positioned geometrically and refined using a riding model. All calculations were performed using the WinGX program package. ${ }^{[24]} \mathrm{CCDC} 1509743\left(\mathbf{3 a}, \mathrm{C}_{50} \mathrm{H}_{41} \mathrm{NO}_{2}\right)$ and $1509742\left(\mathbf{4 b}, \mathrm{C}_{30} \mathrm{H}_{27} \mathrm{NO}_{2}\right)$ contain the supplementary crystallographic data for this paper. These data can be obtained free of charge from the Cambridge Crystallographic Data Centre via www.ccdc.cam.ac.uk/data_request/cif.

Crystal data for 3a: Crystal System $=$ Triclinic, $a=11.2876(9) \AA, b=12.3471(11) \AA, c=14.2761(13) \AA, \alpha=$ $105.390(3)^{\circ}, \beta=93.946(3)^{\circ}, \gamma=102.520(3)^{\circ}, V=1855,7(3) \AA^{3}$, space group $=P-1, Z=2, d_{\text {calc }}=1.231 \mathrm{mg} / \mathrm{mm}^{3}$, Total refs. $=18244$, Unique refs. $=8395$, Final $\mathrm{R}$ indices $[I>2 \operatorname{sigma}(\mathrm{I})] R_{I}=0.0905, w R 2=0.1936, R$ indices (all data) $R_{1}=0.2363, w R_{2}=0.2822$. $(\mathrm{CCDC} 1509743)$.

Crystal data for $\mathbf{4 b}$ : Crystal System $=$ Triclinic, $a=8.7943(6) \AA, b=9.6102(7) \AA, c=14.6459(13) \AA, \alpha=$ $85.498(3)^{\circ}, \beta=85.333(3)^{\circ}, \gamma=64.507(2)^{\circ}, V=1112.28(15) \AA^{3}$, space group $=P-1, Z=2, d_{\text {calc }}=1.294 \mathrm{mg} / \mathrm{mm}^{3}$, Total refs. $=10640$, Unique refs. $=4892$, Final $R$ indices $[I>2 \operatorname{sigma}(\mathrm{I})] R_{I}=0.0490, w R_{2}=0.1218, R$ indices (all data) $R_{1}=0.0758, w R_{2}=0.1501 .(\mathrm{CCDC} 1509742)$.

\section{Acknowledgements}

This study was supported by Hyogo prefecture and a JSPS Grant-in-Aid for Scientific Research (C) (JP16K05896 and JSPS KAKENHI Grant Number JP15H00959). We special thank to Dr. Akihito Konishi at Osaka University for the measurements of Mass and HRMS spectra.

Supporting Information Available. Selected absorption and fluorescence spectra, concentration-dependent ${ }^{1} \mathrm{H}$

NMR of $\mathbf{4 b}$ and $\mathbf{5 b}$. ${ }^{1} \mathrm{H}$ and ${ }^{13} \mathrm{C}$ NMR spectra of new compounds $\mathbf{2 a}, \mathbf{3 a}, \mathbf{4 b}$ and $\mathbf{5 b}$. CIF files of $\mathbf{3 a}$ and $\mathbf{4 b}$. These materials are available free of charge via the Internet at http://pubs.acs.org. 
[1] Reviews on fluorescent sensors: a) Zheng, H.; Zhan, X.-Q.; Bian, Q.-N.; Zhang, X.-J. Chem. Commun. 2013 , 49, 429 - 447; b) Schaferling, M. Angew. Chem. Int. Ed. 2012, 51, 3532 - 3554; c) Sinkeldam, R. W.; Greco, N. J.; Tor, Y. Chem. Rev. 2010, 110, 2579 - 2619; d) Duke, R. M.; Veale, E. B.; Pfeffer, F. M.; Kruger, P. E.; Gunnlaugsson, T. Chem. Soc. Rev. 2010, 39, 3936 - 3953; e) Kim, J. S.; Quang, D. T. Chem. Rev. 2007, 107, 3780-3799; f) Thomas III., S. W.; Joly, G. D.; Swager, T. M. Chem. Rev. 2007, 107, 1339 - 1386; g) Basabe-Desmonts, L.; Reinhoudt, D. N.; Crego-Calama, M. Chem. Soc. Rev. 2007, 36, 993 - 1017.

[2] Recent papers related to solvatofluorochromism: a) Li, S.; Shang, Y.; Wang, L.; Kwok, R. T.; Tang, B. Z. J. Mater. Chem. C 2016, 4, 5363 - 5369; b) Lukasiewicz, L. G.; Deperasinska, I.; Poronik, Y. M.; Jun, Y. W.; Banasiewicz, M.; Kozankeiwicz, B.; Ahn, K. H.; Gryko, D. T. Chem. Asian J. 2016, 11, 1718 - 1724; c) Park, Y. I.; Postupna, O.; Zhugayevych, A.; Shin, H.; Park, Y.-S.; Kim, B.; Yen, H.-J.; Cheruku, P.; Martinez, J. S.; Park, J. W.; Tretiak, S.; Wang, H.-L. Chem. Sci. 2015, 6, 789 - 797; d) Beppu, T.; Tomiguchi, K.; Masuhara, A.; Pu, Y.-J.; Katagiri, H. Angew. Chem. Int. Ed. 2015, 54, 7332 - 7335; e) Kojima, M.; Hayashi, H.; Aotake, T.; Ikeda, S.; Suzuki, M.; Aratani, N.; Kuzuhara, D.; Yamada, H. Chem. Asian J. 2015, 10, 2337 - 2341; f) Friese, D. H.; Mikhaylov, A.; Krzeszewski, M.; Poronik, Y. M.; Rebane, A.; Ruud, K.; Gruko, D. T. Chem. Eur. J. 2015, 21, 18364 - 18374; g) Rajamalli, P.; Gandeepan, P.; Huang, M.-J.; Cheng, C.-H. J. Mater. Chem. C 2015, 3, 3329 - 3335; h) Annaka, T.; Nakata, N.; Ishii, A. Bull. Chem. Soc. Jpn. 2015, 88, 554 - 561; i) Fukazawa, A.; Osaki, H.; Yamaguchi, S. Asian J. Org. Chem. 2014, 3, 122 - 127; j) Guo, Z.-H.; Jin, Z.-X.; Wang, J.-Y.; Pei, J. Chem. Commun. 2014, 50, 6088 - 6090; k) Inouchi, T.; Nakashima, T.; Kawai, T. Chem. Asian J. 2014, 9, 2542 - 2547; 1) Schade, A.; Menzel, R.; Görls, H.; Spange, S.; Beckert, R. Asian J. Org. Chem. 2013, 2, 498 - 503; m) Ding, L.; Zhang, Z.; Li, X.; Su, J. Chem. Commun. 2013, 49, 7319 - 7321; n) Li, J.; Hu, G.; Li, X.; Hu, B.; Wang, N.; Lu, P.; Wang, Y. Eur. J. Org. Chem. 2013, 7320 - 7327; o) Tao, T.; Ma, B.-B.; Peng, Y.-X.; Wang, X.-X.; Huang, W.; You, X.-Z. J. Org. Chem. 2013, 78, 8669 - 8679.

[3] Review articles for the ICT: a) Grabowski, Z. R.; Rotkiewicz, K.; Rettig, W. Chem. Rev. 2003, 103, 3899 4032; b) Sasaki, S.; Drummen, G. P. C.; Konishi, G. J. Mater. Chem. C 2016, 4, 2731 - 2743.

[4] Recent papers related to phthalimide derivatives with a "push-pull” structure: a) Li, M.; Zhang, C.; Shi, L.; Tang, Z.; Chen, C.-F. Chem. Commun. 2016, 52, 9921 - 9924; b) Nishida, J.; Ohura, H.; Kita, Y.; Hasegawa, 
H.; Kawase. T.; Takada, N.; Sato, H.; Sei, Y.; Yamashita, Y. J. Org. Chem. 2016, 81, 433 - 441; c) Wender, P. A.; Jeffreys, J. S.; Raub, A. G. J. Am. Chem. Soc. 2015, 137, 9088 - 9093; d) Li, Y.-Y.; Lu, H.-Y.; Li, M.; Li, X.-J.; Chen, C.-F. J. Org. Chem. 2014, 79, 2139 - 2147; e) Li, M.; Yao, W.; Chen, J.-D.; Lu, H.-Y.; Zhao, Y.; Chen, C.-F. J. Mater. Chem. C 2014, 2, 8373 - 8380; f) Kindahl, T.; Chorell, E. Org. Biomol. Chem. 2014, 12, 4461 - 4470; g) Chen, F.; Zhang, J.; Jiang, H.; Wan, X. Chem. Asian J. 2013, 8, 1497 - 1503.

[5] a) Shi, K.; Lei, T.; Wang, X.-Y.; Wang, J.-Y.; Pei, J. Chem. Sci. 2014, 5, 1041 - 1045; b) Zheng, Y.-Q.; Dai, Y.-Z.; Zhou, Y.; Wang, J.-Y.; Pei, J. Chem. Commun. 2014, 49, 1591 - 1594; c) Zhou, Y.; Dai, Y.-Z.; Zheng, Y.-Q.; Wang, X.-Y.; Wang, J.-Y.; Pei, J. Chem. Commun. 2013, 49, 5802 - 5804; d) Li, H.; Kim, F. S.; Ren, G.; Hollenbeck, E. C.; Subramaniyan, S.; Jenekhe, S. A. Angew. Chem. Int. Ed. 2013, 52, 5513 - 5517; e) Schmidt, B. M.; Topolinski, B.; Roesch, P.; Lentz, D. Chem. Commun. 2012, 48, 6520 - 6522; f) Zhou, Y.; Ding, L.; Shi, K.; Dai, Y.-Z.; Pei, J. Adv. Mater. 2012, 24, 957 - 961; g) Vanel, R.; Berthiol, F.; Bessieres, B.; Einhorn, C.; Einhorn, J. Synlett 2011, 9, 1293 - 1295; h) Ding, L.; Ying, H.-Z.; Zhou, Y.; Lei, T.; Pei, J. Org. Lett., 2010, 12, 5522 - 5525; i) Duan, L.; Xu, Y.; Qian, X.; Zhang, Y.; Liu, Y. Tetrhadron Lett. 2009, 50, 22 - 25.

[6] First synthesis of $N$-alkylacenaphthylene-5,6-dicarboxyimides was reported in the following paper. Our works were performed independently. Lin, D.; Yang, C.; Su, Z.; Pei, J. Sci. China Chem. 2015, 58, 364 - 369.

[7] Review articles for self-aggregation behaviour of PAH bisimides: a) Liu, Z.; Sun, J.; Zhou, Y.; Zhang, Y.; Wu, Y.; Nalluri, S. K. M.; Wang, Y.; Samanta, A.; Mirkin, C. A.; Schatz, G. C.; Stoddart, J. F., J. Org. Chem. 2016, 81, 2581 - 2588; de Oliveira Santos, D. M.; Belarmino Cabral, M. G.; Bentaleb, A.; Cristano, R.; Gallardo, H.; Durola, F.; Bock, H. Chem. Eur. J. 2016, 22, 7389 - 7393; Prentice, G. M.; Pascu, S. I.; Filip, S. V.; West, K. R.; Pantos, G. D. Chem. Commun. 2015, 51, 8265 - 8268; D’Anna, F.; Marullo, S.; Lazzara, G.; Vitale, P.; Noto, R. Chem. Eur. J. 2015, 23, 14780 - 14790; Ma, X.; Zhang, Y.; Zheng, Y.; Zhang, Y.; Tao, X.; Che, Y.; Zhao, J. Chem. Commun. 2015, 51, 4231 - 4233; Prajitha, K. P.; Chithiravel, S.; Krishnamoorthy, K.; Asha, S. K. J. Mater. Chem. C 2014, 2, 9882 - 9891; Kulkarni, C.; George, S. J. Chem. Eur. J. 2014, 20, 4537-4541; Molla, M. R.; Gehrig, D.; Roy, L.; Kamm, V.; Paul, A.; Laquai, F.; Ghosh, S. Chem. Eur. J. 2014, 20,760 771.

[8] Ozoe, H., Kitamura, C.; Kurata, H.; Nishida, J.; Kawase, T. Chem. Lett. 2014, 43, 1467 - 1469.

[9] Frisch, M. J.; Trucks, G. W.; Schlegel, H. B.; Scuseria, G. E.; Robb, M. A.; Cheeseman, J. R.; Scalmani, G.; 
Barone, V.; Mennucci, B.; Petersson, G. A.; Nakatsuji, H.; Caricato, M.; Li, X.; Hratchian, H. P.; Izmaylov, A. F.; Bloino, J.; Zheng, G.; Sonnenberg, J. L.; Hada, M.; Ehara, M.; Toyota, K.; Fukuda, R.; Hasegawa, J.; Ishida, M.; Nakajima, T.; Honda, Y.; Kitao, O.; Nakai, H.; Vreven, T.; Montgomery, Jr., J. A.; Peralta, J. E.; Ogliaro, F.; Bearpark, M.; Heyd, J. J.; Brothers, E.; Kudin, K. N.; Staroverov, V. N.; Kobayashi, R.; Normand, J.; Raghavachari, K.; Rendell, A.; Burant, J. C.; Iyengar, S. S.; Tomasi, J.; Cossi, M.; Rega, N.; Millam, J. M.; Klene, M.; Knox, J. E.; Cross, J. B.; Bakken, V.; Adamo, C.; Jaramillo, J.; Gomperts, R.; Stratmann, R. E.; Yazyev, O.; Austin, A. J.; Cammi, R.; Pomelli, C.; Ochterski, J. W.; Martin, R. L.; Morokuma, K.; Zakrzewski, V. G.; Voth, G. A.; Salvador, P.; Dannenberg, J. J.; Dapprich, S.; Daniels, A. D.; Farkas, O.; Foresman, J. B.; Ortiz, J.; Cioslowski, J. V.; Fox, D. J. Gaussian 09 (Revision A.02), Gaussian, Inc., Wallingford CT, 2009.

[10] Li, H.; Kim., S.; Ren, G.; Hollenbeck, E. C.; Subramaniyan, S.; Jenekhe, S. A. Angew. Chem. Int. Ed. 2013, $52,5513-5517$.

[11] Barbarella, G.; Favaretto, L.; Sotgiu, G.; Zambianchi, M.; Bohgini, A.; Arbizzani, C.; Mastragostino, M.; Anni, M.; Gigli, G.; Cingolani, R. J. Am. Chem. Soc., 2000, 122, 11971-11978.

[12] a) Cava, M. P.; Shirley, R. L. J. Am. Chem. Soc. 1960, 82, 654 - 656; b) Cava, M. P.; Napier, D. R. J. Am. Chem. Soc. 1957, 79, $1701-1705$.

[13] Swartz, C. R.; Parkin, S. R.; Bullock, J. E.; Anthony, J. E.; Mayer, A. C.; Malliaras, G. G. Org. Lett., 2005, $3163-3166$.

[14] Man, Y.-M.; Mak, T. C. W.; Wong, H. N. C. J. Org. Chem. 1990, 55, 3214-3221.

[15] a) Martin, R. B. Chem. Rev. 1996, 96, 3043 - 3064; b) Rahman, M. J.; Shimizu, H.; Araki, Y.; Ikeda, H.; Iyoda, M. Chem. Commun. 2013, 49, $9251-9253$.

[16] a) Bangal, P. R.; Panja, S.; Chakravorti, S. J. Photochem. Photobiol., A 2001, 139, 5 - 16; b) Loutfy, R. O.; Arnold, B. A. J. Phys. Chem., 1982, 86, $4205-4211$.

[17] Mataga, N.; Kaifu, Y.; Koizumi, M. Bull. Chem. Soc. Jpn. 1956, 29, 465 - 470.

[18] Lin, H.-H.; Chan, Y.-C.; Chen, J.-W.; Chang, C.-C. J. Mater. Chem. 2011, 21, 3170 - 3177.

[19] Raoui, M.; Massue, J.; Azarias, C.; Jacquemin, D.; Ulrich, G. Chem. Commun. 2016, 52, 9216 - 9219, and see references in there.

[20] a) Lakowicz, J. R. in Principles of Fluorescence Spectroscopy, Springer, 2006, pp 1-21; b) Samori, S.; Tojo, 
S.; Fujitauka, M.; Spitler, E. L.; Haley, M. M.; Majima, T. J. Org. Chem. 2007, 72, 2785 - 2793; c) Fakhara, A. Rokita, M., S. E. Chem. Commun. 2011, 47, $4422-4424$.

[21] Morris, X. J. V.; Mahaney, M. A.; Huber, J. R. J. Phys. Chem. 1976, 80, 969 - 974.

[22] Burla, M. C.; Caliandro, R.; Camalli, M.; Carrozini, B.; Cascarano, G. L.; De Caro, L.; Giacovazzo, C.; Polidori, G.; Spagna, R. J. Appl. Crystallogr. 2005, 38, 381 - 388.

[23] Sheldrick, G. M. Acta Crystallogr. Sect. C 2015, 71, 3 - 8.

[24] Farrugia, L. J. J. Appl. Cryst. 2012, 45, 849 - 854. 


\section{Schemes, Figures and Tables}

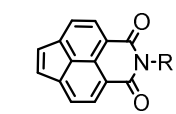

1a: $R=$ Ehex

1b: $R=$ Oct

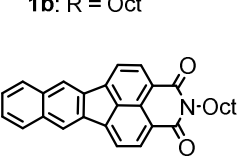

BFI: 4b

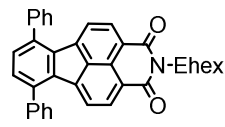

DPFI: 2a

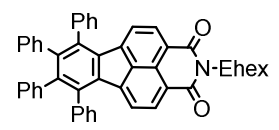

TPFI: $\mathbf{3 a}$ Oct

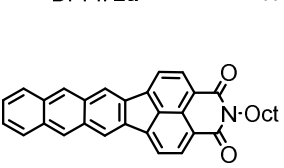

$\mathrm{NFI}: \mathbf{5 b}$

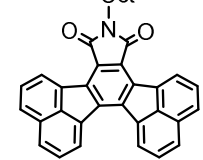

$6 b$

Scheme 1

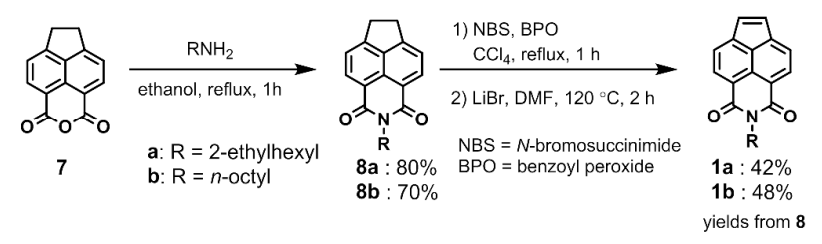

Scheme 2.

a)

$1 \mathrm{a}$
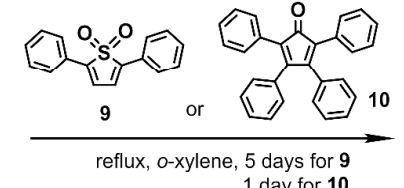

5 days for 9
1 day for 10

(l)

b) $1 \mathrm{~b}$

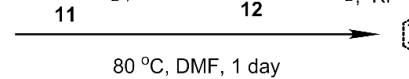

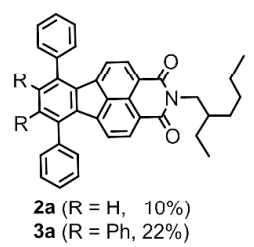

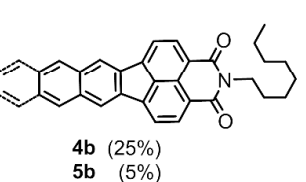

Scheme 3. Synthesis of $\mathbf{2 a}, \mathbf{3 a}, \mathbf{4 b}$, and $\mathbf{5 b}$ from $\mathbf{1}$.

Equation 1

$$
\Delta_{\mathrm{SS}}=v_{\mathrm{abs}}-v_{\mathrm{em}}=\frac{2 \Delta \mu^{2}}{\mathrm{hc \textrm {a } ^ { 3 }}} \Delta \mathrm{f}+\mathrm{const}
$$


Table 1. Absorption and fluorescence spectral data of the $\pi$-extended FI derivatives in $\mathrm{CH}_{2} \mathrm{Cl}_{2}$.

\begin{tabular}{cccc}
\hline & $\lambda_{\mathrm{ABS}}(\log \varepsilon)^{[\mathrm{a}]}$ & $\lambda_{\mathrm{EX}}{ }^{[\mathrm{b}]}$ & $\Phi_{\mathrm{SL}}{ }^{[\mathrm{c}]}$ \\
\hline 1a & $305(3.75), 321(3.85), 339$ & 389,409, & \\
& $(3.94)$, & $435 \mathrm{~s}$ & 0.04 \\
2a & $291(4.38), 365(3.82), 422(4.16)$ & 511 & 0.02 \\
& $291(4.50), 348(3.71), 366$ & & \\
3a & $(3.92), 422(4.30)$ & 537 & 0.01 \\
4b & $307(4.48), 328(4.36), 432$ & & 0.29 \\
& $(4.27), 459(4.32)$ & $493,525 \mathrm{~s}$ & \\
\hline & $277(4.76), 354(4.55), 479$ & & 0.37 \\
\hline
\end{tabular}

[a] Absorption maxima in $\mathrm{CH}_{2} \mathrm{Cl}_{2}$. [b] Fluorescence maxima in $\mathrm{CH}_{2} \mathrm{Cl}_{2} . \lambda_{\mathrm{EX}}=365 \mathrm{~nm}\left(\mathrm{ca} .10^{-5} \mathrm{M}\right)$. [c] Fluorescence quantum yields $( \pm 10 \%)$ in $\mathrm{CH}_{2} \mathrm{Cl}_{2}$ determined relative to 9,10-diphenylanthracene as an actinometer.

Table 2. Experimental reduction potentials and energy gaps of $\mathbf{2 b}, \mathbf{3 b}, \mathbf{4 a}$ and $\mathbf{5 a}$, and DFT calculated electronic properties of $\mathbf{2 c - 5 c}$.

\begin{tabular}{cccccccc}
\hline compounds & $\begin{array}{c}E_{\text {red }}^{1} \\
(\mathrm{~V})^{[\mathrm{a}]}\end{array}$ & $\begin{array}{c}E_{\text {red }}^{2} \\
(\mathrm{~V})^{[\mathrm{a}]}\end{array}$ & $\begin{array}{c}E_{\mathrm{HOMO}} \\
(\mathrm{eV})\end{array}$ & $\begin{array}{c}E_{\mathrm{LUMO}} \\
(\mathrm{eV})\end{array}$ & $\begin{array}{c}\left.\Delta E_{\mathrm{cal}}\right] \\
(\mathrm{eV})^{[\mathrm{b}]}\end{array}$ & $\begin{array}{c}\Delta E_{\mathrm{obs}} \\
(\mathrm{eV})^{\mathrm{c}]}\end{array}$ & $\begin{array}{c}\text { Dipole } \\
\text { moment } \\
(\text { Debye })\end{array}$ \\
\hline $\mathbf{2}$ & -1.01 & -1.41 & -6.04 & -2.75 & 3.29 & 2.46 & 5.23 \\
$\mathbf{3}$ & -1.10 & -1.51 & -6.17 & -2.62 & 3.55 & 2.42 & 5.76 \\
$\mathbf{4}$ & -0.97 & -1.38 & -5.90 & -2.76 & 3.14 & 2.41 & 5.45 \\
$\mathbf{5}$ & -0.97 & -1.37 & -5.49 & -2.70 & 2.79 & 2.09 & 6.18 \\
\hline
\end{tabular}

[a] vs. $\mathrm{Ag} / \mathrm{Ag}^{+}$, in $0.1 \mathrm{M} \mathrm{n}-\mathrm{Bu}_{4} \mathrm{NClO}_{4} / \mathrm{CH}_{2} \mathrm{Cl}_{2}$, scan rate: $100 \mathrm{mVs}{ }^{-1}, \mathrm{Fc} / \mathrm{Fc}^{+}=0 \mathrm{~V}$. [b] $\Delta E_{\text {cal }}=E_{\mathrm{LUMO}}-E_{\mathrm{HOMO}}$ [B3LYP/6-31G(d)]. [c] From the low energy absorption edge of the absorption spectra in $\mathrm{CH}_{2} \mathrm{Cl}_{2}$. 
Chaptions of Scheme, Figure and Tables

Scheme 1. Acenaphthene imides $\mathbf{1 a}$ and $\mathbf{1 b}$, and $\pi$-extended FI derivatives $\mathbf{2 a}, \mathbf{3 a}, \mathbf{4 b}, \mathbf{5 b}$, and $\mathbf{6 b}$.

Scheme 2. Synthesis of $\mathbf{1 a}$ and $\mathbf{1 b}$ from anhydride 7.

Scheme 3. Synthesis of $\mathbf{2 a}, \mathbf{3 a}, \mathbf{4 b}$, and $\mathbf{5 b}$ from $\mathbf{1}$.

Figure 1. ORTEP drawings of (a) Top view and (b) side view of 3a. (c) A packing structure and the closest distance of the FI moieties of $\mathbf{3 a}$.

Figure 2. ORTEP drawings of (a) top view and (b) side view of $\mathbf{4 b}$. (c) A columnar $\pi$ - $\pi$ stacking structure and closest distance of $\mathbf{4 b}$ moieties. Octyl carbons were omitted for the sake of clarity.

Figure 3. (a) Absorption and (b) normalized fluorescence spectra $\left(\lambda_{\mathrm{EX}}=365 \mathrm{~nm}, \mathrm{ca} .10^{-5} \mathrm{M}\right)$ of $\mathbf{1 a}$ and the $\pi$-extended FI derivatives, $\mathbf{2 a}, \mathbf{3 a}, \mathbf{4 b}$ and $\mathbf{5 b}$ in $\mathrm{CH}_{2} \mathrm{Cl}_{2}$.

Table 1. Absorption and fluorescence spectral data of the $\pi$-extended FI derivatives in $\mathrm{CH}_{2} \mathrm{Cl}_{2}$.

[a] Absorption maxima in $\mathrm{CH}_{2} \mathrm{Cl}_{2}$. [b] Fluorescence maxima in $\mathrm{CH}_{2} \mathrm{Cl}_{2} \cdot \lambda_{\mathrm{EX}}=365 \mathrm{~nm}\left(\mathrm{ca} .10^{-5} \mathrm{M}\right)$. [c]

Fluorescence quantum yields $( \pm 10 \%)$ in $\mathrm{CH}_{2} \mathrm{Cl}_{2}$ determined relative to 9,10-diphenylanthracene as an actinometer.

Figure 4. Concentration-dependent ${ }^{1} \mathrm{H}-\mathrm{NMR}$ spectra of aromatic range of $\mathbf{5 b}$ from $1 \times 10^{-4}$ to $2.0 \times 10^{-2} \mathrm{M}$ at $20{ }^{\circ} \mathrm{C}$ in $\mathrm{CDCl}_{3}$.

Figure 5. Fluorescence colors (photographs) and normalized fluorescence spectra of $\mathbf{5 b}$ in cyclohexane, toluene, $\mathrm{CH}_{2} \mathrm{Cl}_{2}, \mathrm{CH}_{3} \mathrm{CN}$ and $\mathrm{CH}_{3} \mathrm{OH}\left(\right.$ ca. $\left.10^{-5} \mathrm{M}, \lambda_{\mathrm{EX}}=365 \mathrm{~nm}\right)$.

Figure 6. a) The Lippert-Mataga plot for $\mathbf{4 b}$ and $\mathbf{5 b}$; Stokes shift versus the Lippert solvent parameter $\Delta f$ (correlation for $\mathbf{4 b}(---), y=9106.5 \mathrm{x}-551.36, R^{2}=0.8833$, and for $\mathbf{5 b}(-), \mathrm{y}=6653.5 \mathrm{x}-347.22, R^{2}=0.9254$ ). 
b) Correlation of peak emission wavenumber of with solvent polarity parameter $E_{\mathrm{T}}(30)$ (correlation for $\mathbf{4 b}(---)$, $R^{2}=0.9527$, and for $\left.\mathbf{5 b}(-), R^{2}=0.9362\right)$.

Figure 7. Optimized conformations and calculated spatial electron distributions of the HOMO and LUMO for $\mathbf{2 c -}$ 5c obtained by DFT calculations at B3LYP/6-31G(d) level.

Table 2. Experimental reduction potentials and energy gaps of $\mathbf{2 b}, \mathbf{3 b}, \mathbf{4 a}$ and $\mathbf{5 a}$, and DFT calculated electronic properties of $\mathbf{2} \mathbf{c}-\mathbf{5 c}$.

[a] vs. $\mathrm{Ag} / \mathrm{Ag}^{+}$, in $0.1 \mathrm{M} n-\mathrm{Bu}_{4} \mathrm{NClO}_{4} / \mathrm{CH}_{2} \mathrm{Cl}_{2}$, scan rate: $100 \mathrm{mVs}^{-1}, \mathrm{Fc} / \mathrm{Fc}^{+}=0 \mathrm{~V}$. [b] $\Delta E_{\text {cal }}=E_{\mathrm{LUMO}}-E_{\mathrm{HOMO}}$ [B3LYP/6-31G(d)]. [c] From the low energy absorption edge of the absorption spectra in $\mathrm{CH}_{2} \mathrm{Cl}_{2}$. 
Figure of abstract
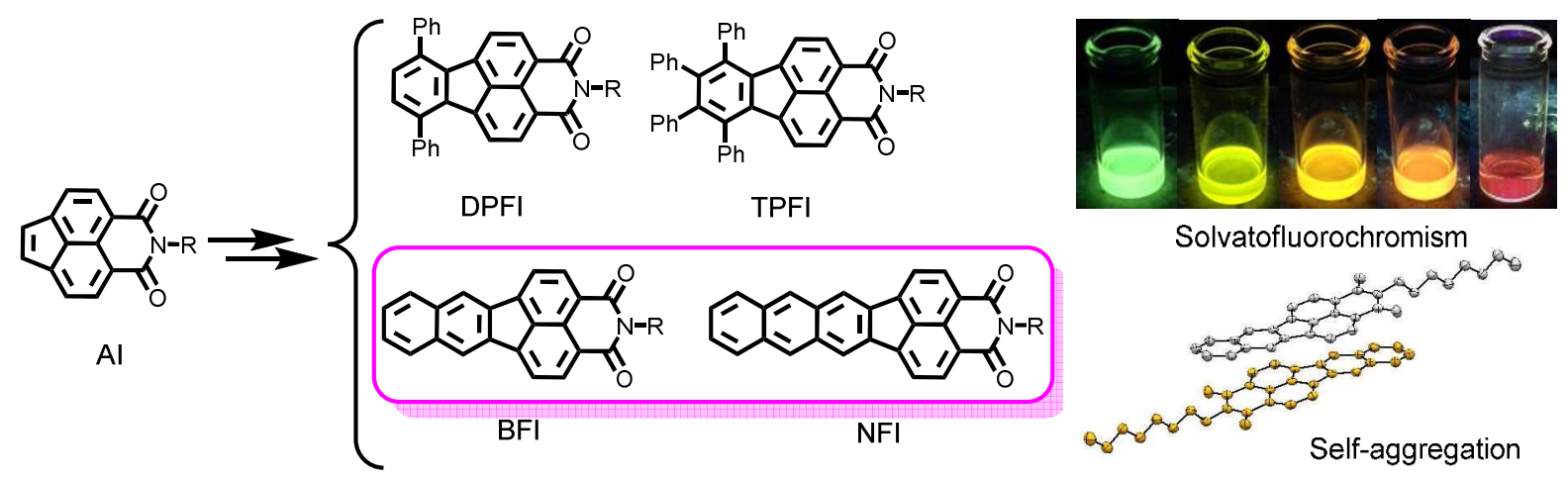


\section{Figure of abstract}

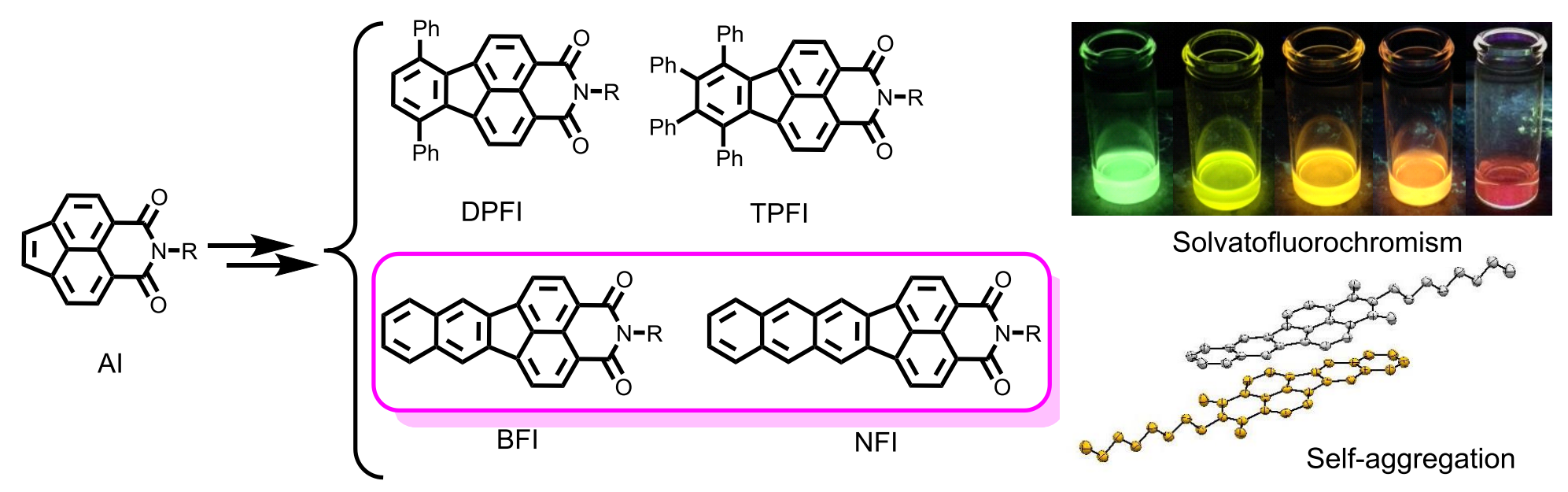


Figure 1

(a)

(b)

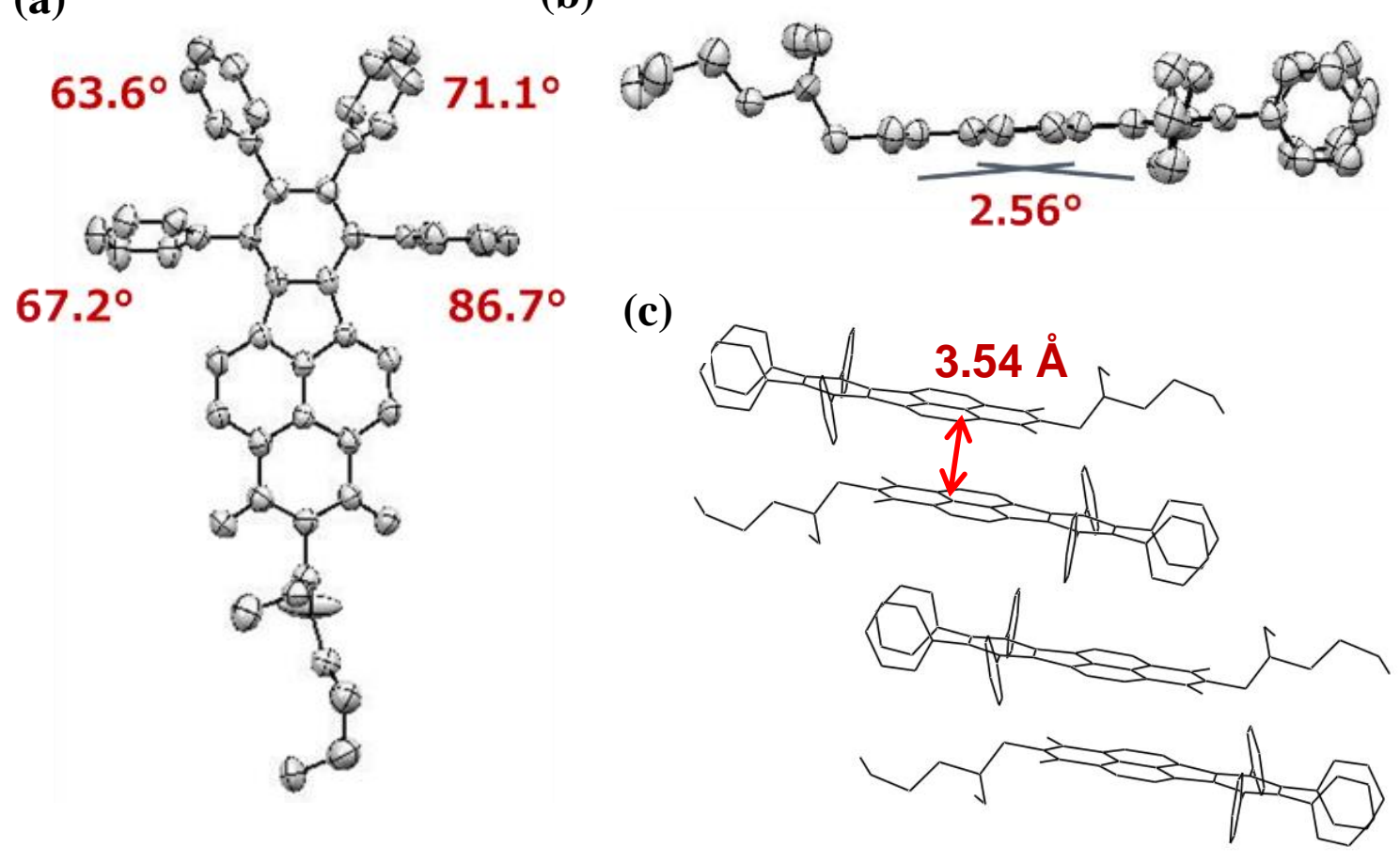


Figure 2

(a)

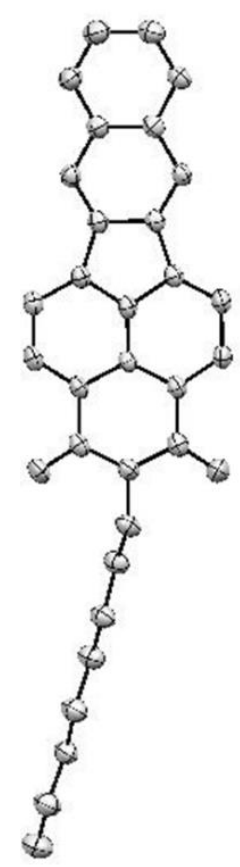

(b)

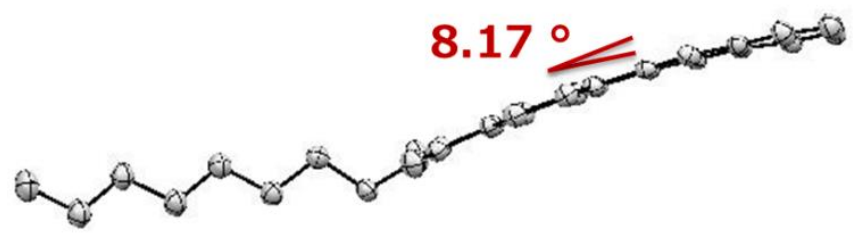

(c)

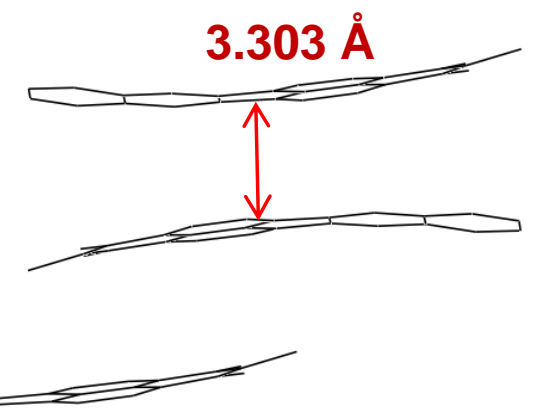




\section{Figure 3}
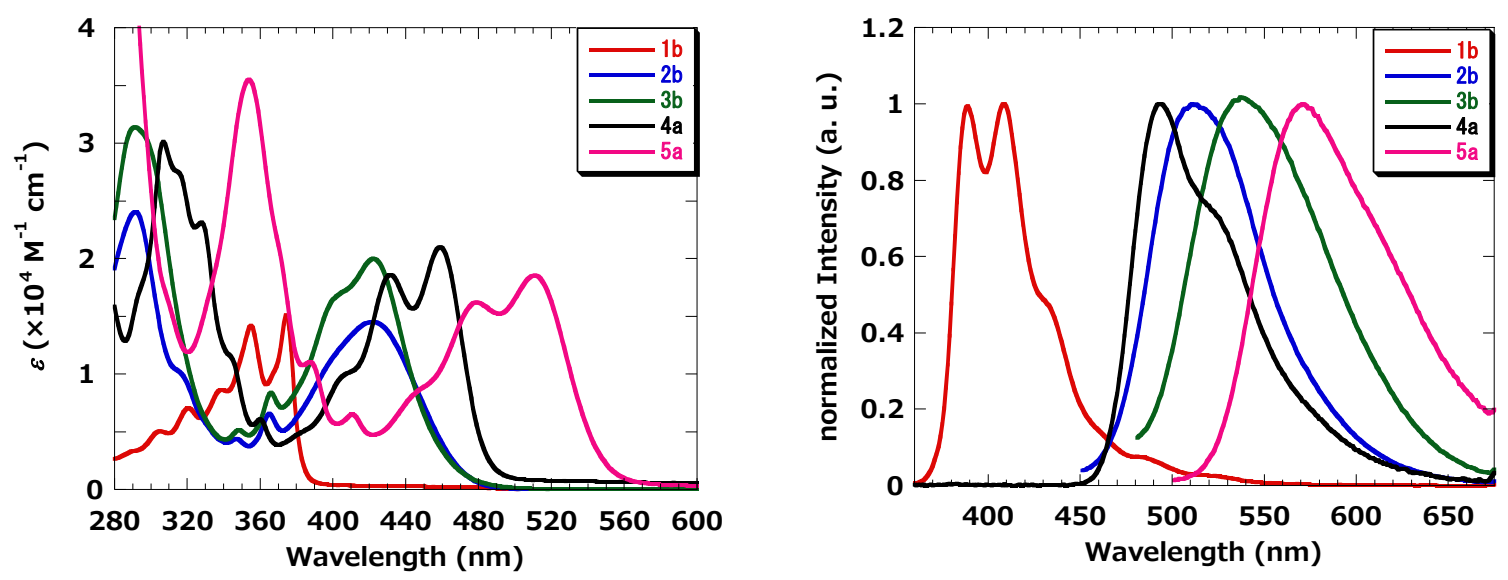


\section{Figure 4}

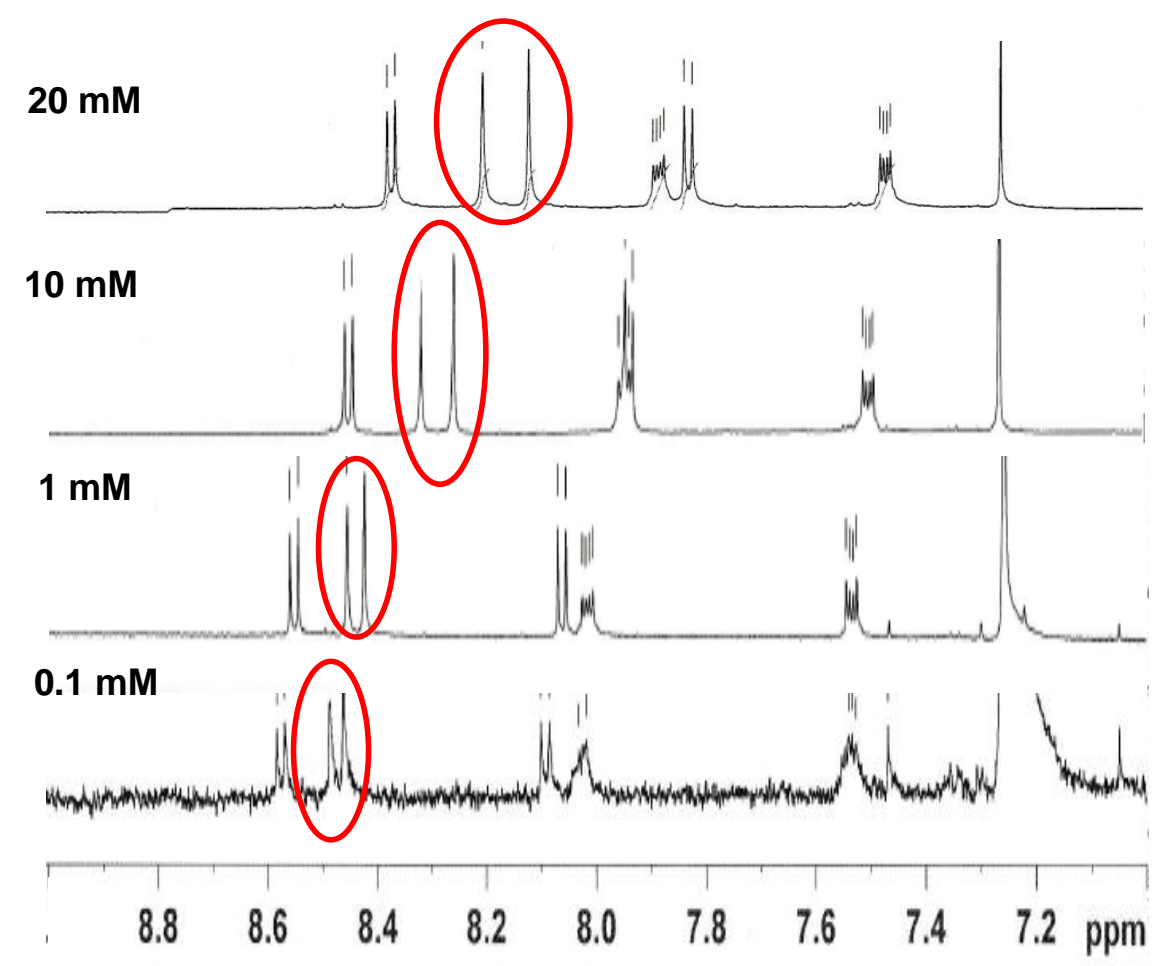

https://mc06.manuscriptcentral.com/cjc-pubs 
Figure 5
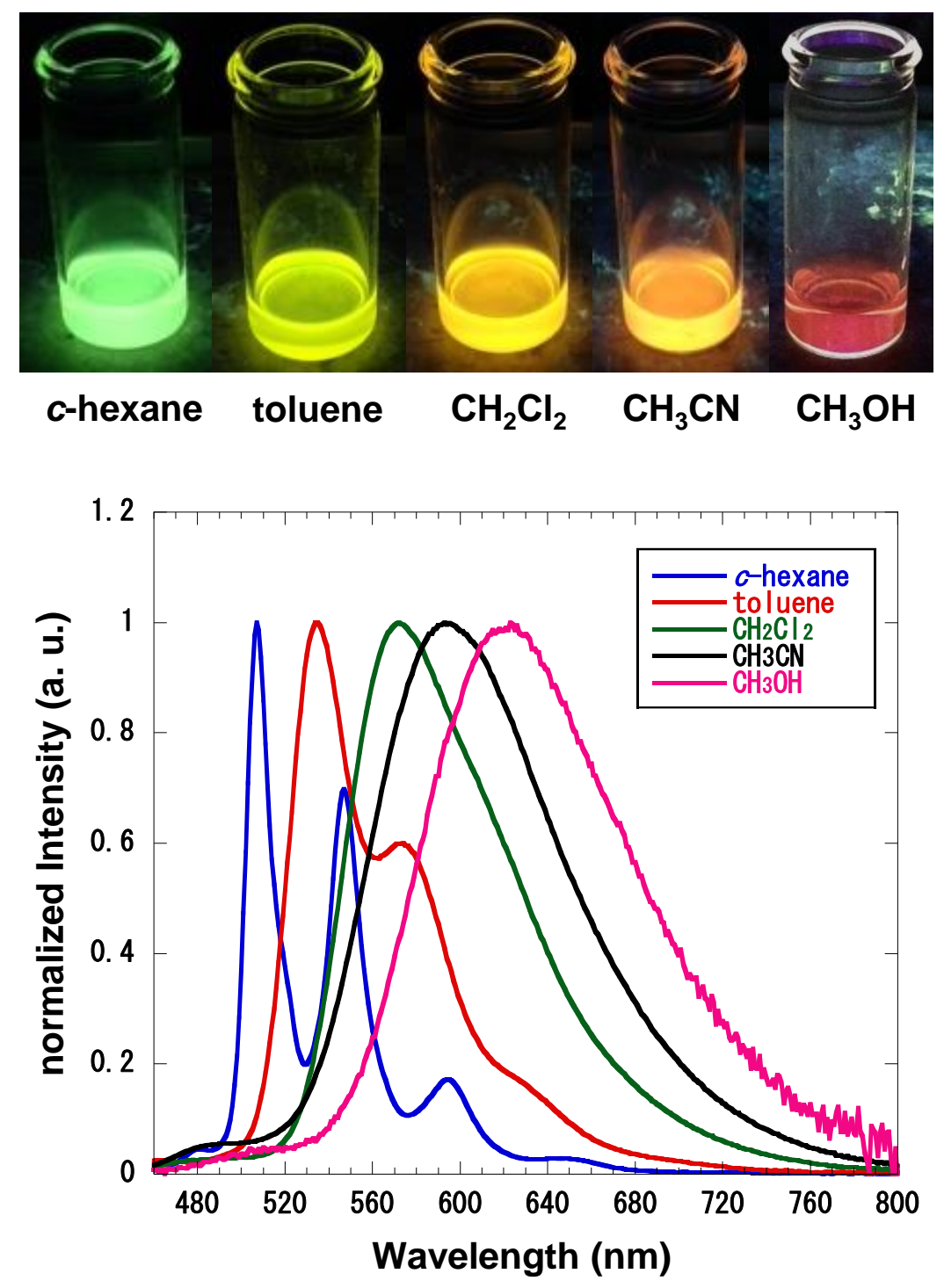

https://mc06.manuscriptcentral.com/cjc-pubs 


\section{Figure 6}

a)

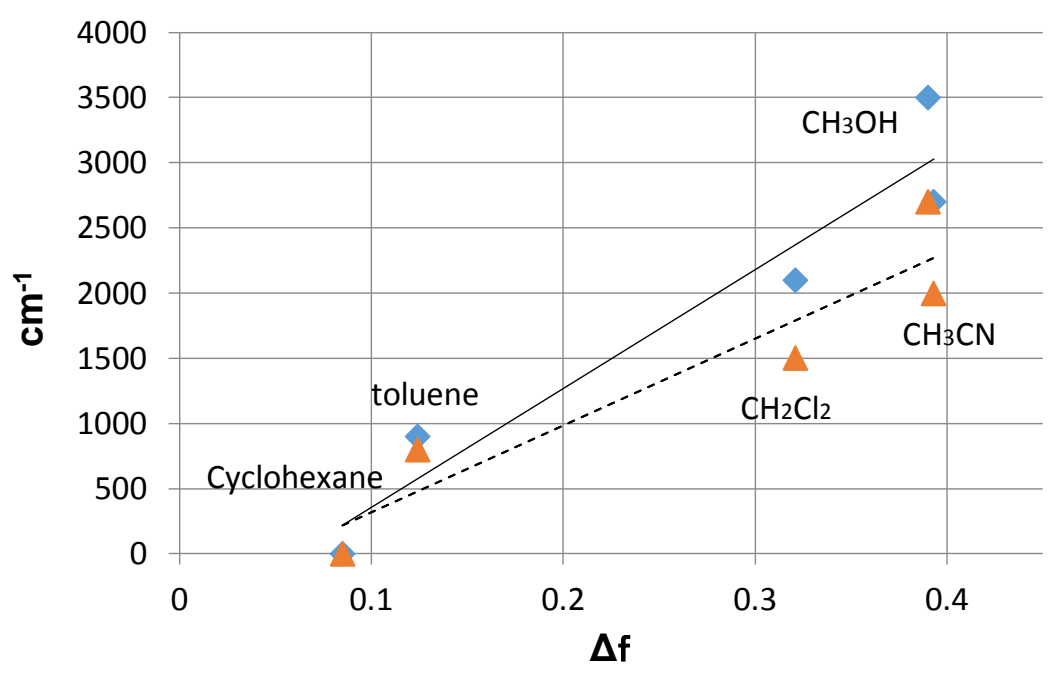

b)

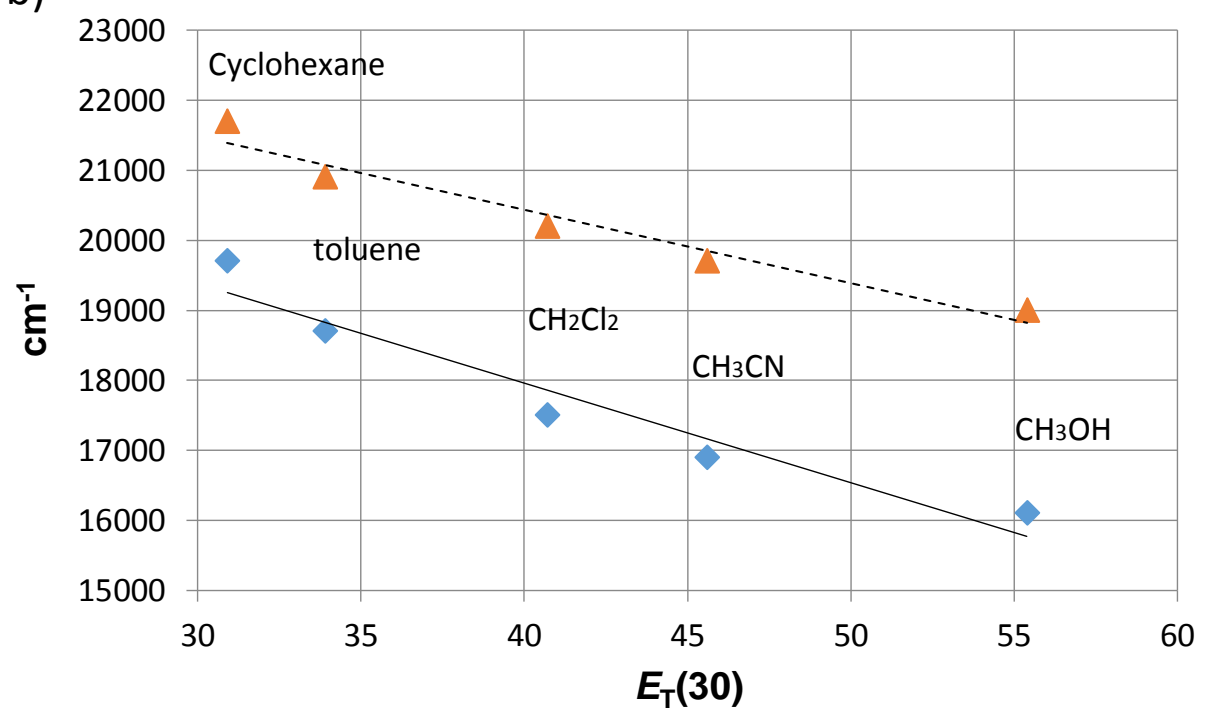


Figure 7

LUMO

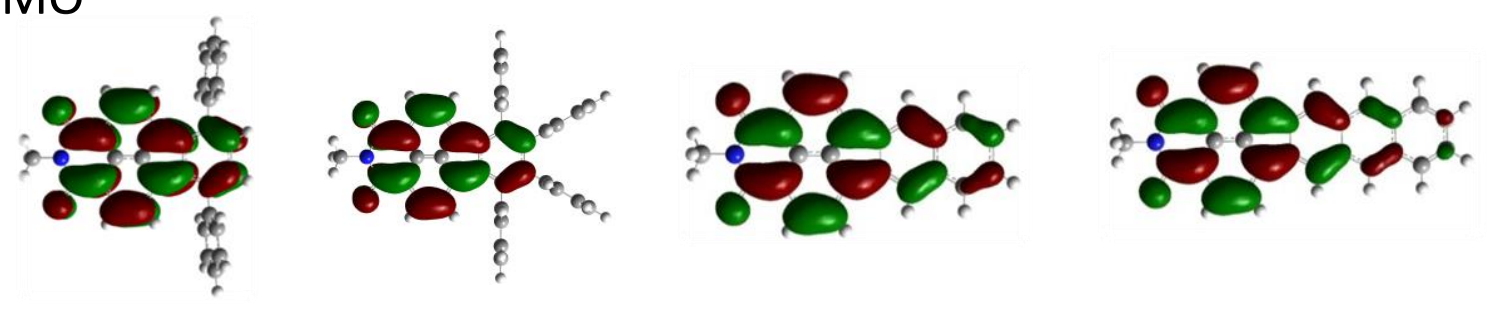

HOMO

@Q98

2c

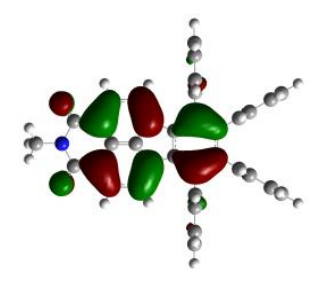

$3 c$
¿0000

4c ¿80́ono

$5 c$ 